\title{
Zirconia and Pyrochlore Oxides for Thermal Barrier Coatings in Gas Turbine Engines
}

\begin{abstract}
JEFFREY W. FERGUS
One of the important applications of yttria-stabilized zirconia (YSZ) is as a thermal barrier coating for gas turbine engines. While YSZ performs well in this function, the need for increased operating temperatures to achieve higher energy conversion efficiencies, requires the development of improved materials. To meet this challenge, some rare-earth zirconates that form the cubic fluorite-derived pyrochlore structure are being developed for use in thermal barrier coatings due to their low thermal conductivity, excellent chemical stability, and other suitable properties. In this paper, the thermal conductivities of current and prospective oxides for use in thermal barrier coatings are reviewed. The factors affecting the variations and differences in the thermal conductivities and the degradation behaviors of these materials are discussed.
\end{abstract}

DOI: $10.1007 / \mathrm{s} 40553-014-0012-\mathrm{y}$

(C) The Minerals, Metals \& Materials Society and ASM International 2014

\section{INTRODUCTION}

THE need for improved energy conversion efficiency has driven efforts to increase the operating temperatures of gas turbine engines. One approach to increasing the operating temperature is to apply ceramic thermal barrier coatings to the metallic turbine blade materials to reduce the temperature of the alloy during use. The development of thermal barrier coating systems includes the identification of new materials and effective processing of those materials. ${ }^{[1-3]}$ Thermal barrier systems contain multiple layers with different functions including a bond coat that provides the needed adherence between the alloy and an outer ceramic thermal barrier coating. ${ }^{[4]}$ The focus of this paper is on the outer ceramic coating material that is exposed to the hot gas in the turbine engine during operation.

The purpose of the thermal barrier coating is to increase the operating temperature by reducing the temperature at the alloy surface, so the critical property of the coating material is low thermal conductivity. The thermal conductivity depends not only on the inherent properties of the material, but also on the microstructure and morphology, so the development of processing techniques to achieve desired microstructures and morphologies is important. During high temperature use, the microstructures, and thus the properties, can change. Phase changes during thermal cycling or from reactions in corrosive environments can also occur and lead to coating degradation. In addition to low thermal conductivity, the coating material should have good compatibility with the alloy, which includes good match in the coefficients of thermal expansion and good chemical compatibility with the alumina scale that forms on the

JEFFREY W. FERGUS, Professor, is with the Materials Research and Education Center, Auburn University, 275 Wilmore Laboratories,

Auburn, AL 36849. Contact e-mail: jwfergus@eng.auburn.edu

Manuscript submitted January 12, 2014.

Article published online April 12, 2014 alloy. ${ }^{[5]}$ Yttria-stabilized zirconia (YSZ) meets these criteria and is the most widely used material for thermal barrier coatings. Although zirconia-based thermal barrier coatings are effective, improved coating systems can lead to further increases in operating temperature and extended stability, which would in turn lead to increased efficiency and lower cost of gas turbine engine energy conversion systems.

\section{THERMAL CONDUCTIVITY}

The development of materials with low thermal conductivity involves the investigation of alternative crystal structures and compositions. ${ }^{[6,7]}$ There are three contributions to the transport of heat through a thermal barrier: electronic conduction, lattice phonons, and radiation. ${ }^{[8]}$ Materials used for thermal barrier coatings are typically electrical insulators, so the contribution from electronic conduction is negligible. ${ }^{[9]}$ Thermal transport by radiation increases with increasing temperature and can be significant at high temperatures, ${ }^{[10,11]}$ but below $1523 \mathrm{~K}\left(1250{ }^{\circ} \mathrm{C}\right)$ less than 10 pct of heat is transferred through radiative heat transport, ${ }^{[8]}$ so the focus of reducing thermal conduction in thermal barrier coating materials is generally focused on contributions from lattice phonons.

Reducing the conduction by lattice phonons can be accomplished by reducing the mean free path of the phonons, reducing the phonon velocity, or reducing the density of the material. The mean free path can be reduced by scattering from lattice imperfections, such as vacancies, dislocations, or grain boundaries. ${ }^{[8,12]}$ Scattering by grain boundaries is typically not a significant factor for conventional materials, but can become significant for nanoscale structures. This is particularly effective if the nanoscale dimension of the microstructure is oriented along the direction of heat flow as in a layered structure. In addition to intrinsic defects, extrinsic defects from doping can increase scattering due to differences in atomic mass, bond strength, or atomic 


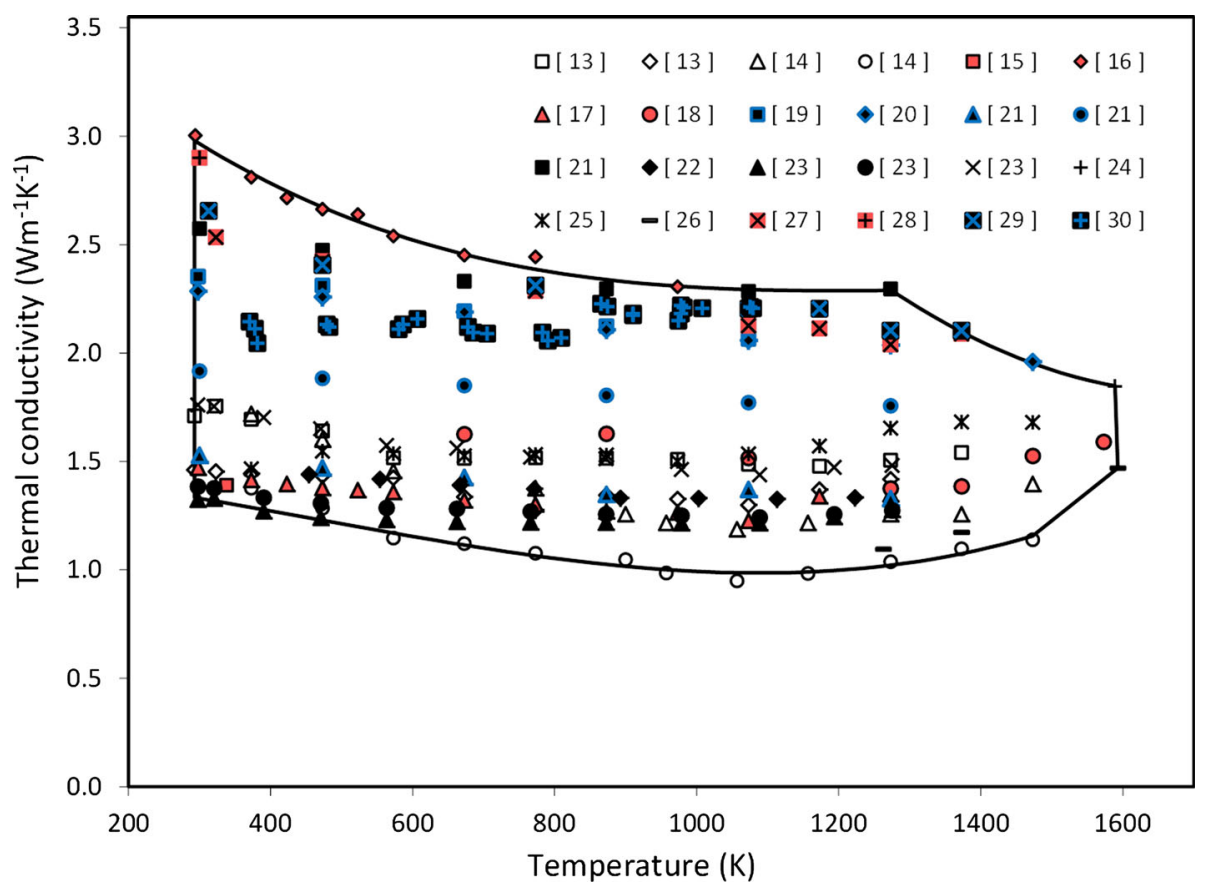

Fig. 1-Thermal conductivity of $\mathrm{YSZ}$ with 7-8 wt pet $\mathrm{Y}_{2} \mathrm{O}_{3}{ }^{[13-30]}$

radius. Lattice phonon velocity is proportional to the square root of the elastic modulus divided by density, so this ratio can be used to identify materials with potentially low thermal conductivities. ${ }^{[5]}$

The most common material used for thermal barrier coatings is zirconia doped with 7-8 wt pet yttria. This amount of yttria is not sufficient for full stabilization of the cubic fluorite phase and instead the tetragonal $t^{\prime}$ phase is formed. Thermal conductivities measured for YSZ with $7-8$ pct yttria are shown in Figure $1 .^{[13-30]}$ Figure 2 shows that the conductivity of the yttria-doped zirconia material is lower than that of pure zirconia. ${ }^{[27-32]}$ Further increase in ytrria content beyond the typical $7-8 \mathrm{wt}$ pct can lead to further decrease in the thermal conductivity as shown in Figure $3 .^{[8,33]}$ Yttrium and zirconium are similar in size and weight, but yttria is trivalent and thus, when doped on the tetravalent zirconium site, creates oxygen vacancies that can scatter phonons and decrease thermal conductivity. The vacancies have the added benefit of reducing radiative heat transfer, which, as noted above is relatively small, but can become significant at high temperatures. ${ }^{[8]}$ While this trend in thermal conductivity would suggest that high yttria contents should be used, there are detrimental effects of high yttria contents. For example, Figure 4 shows that there is a maximum in the lifetime of YSZ thermal barrier coatings, defined as either the time for first crack formation or the number of cycles to failure, at a relatively low yttria content of $6 \mathrm{wt}$ pct. ${ }^{[1,34,35]}$

Like yttria, other dopants can decrease the thermal conductivity of zirconia. ${ }^{[1,6,33]}$ Various lanthanide elements, including lanthanum, ${ }^{[36]}$ gadolinium, ${ }^{[8,37]}$ erbium ${ }^{[8]}$ neodymium, ${ }^{[8,33]}$ dysprosium, ${ }^{[38]}$ and ytterbium ${ }^{[8,20,33,39]}$ have been used to decrease the thermal conductivity of zirconia. Lanthanide doping creates lattice strain which increases lattice anharmonicity and phonon scattering. ${ }^{[8]}$ The amount of strain increases with dopant size, so the thermal conductivity of zirconia decreases with increasing size of the lanthanide dopant ion. ${ }^{[40]}$ Like yttrium, lanthanide elements are trivalent and thus create oxygen vacancies that can scatter phonons. However, lanthanide elements are also heavier than zirconium and thus provide an additional scattering mode. Ytterbium, as one of the heavier lanthanide elements, is especially effective. One example illustrating the effect of ytterbium doping is shown in Figure $5,{ }^{[20]}$ which also includes the range of thermal conductivity for YSZ with 7-8 wt pet $\mathrm{Y}_{2} \mathrm{O}_{3}$ from Figure 1 for comparison.

Combinations of lanthanide elements such as ytterbium with neodymium ${ }^{[25,33]}$ or gadolinium ${ }^{[25,33,41]}$ have been used. The dopants are combined to create immobile clusters of point defects. Such defect clustering in the $t^{\prime}$ zirconia phase has been shown to decrease the thermal conductivity, which reached a minimum value near the composition of the phase boundary between the $t^{\prime}$ and cubic phases. ${ }^{[33]}$ Figure 5 shows that gadolinium is a little more effective than neodymium when used as a co-dopant with ytterbium and yttrium (i.e., compare the results for 7.4 wt pet $\mathrm{Y}, \mathrm{Nd}, \mathrm{Yb}$ with those of 7.4 wt pet $\mathrm{Y}, \mathrm{Gd}, \mathrm{Yb}$ ), and that increased co-dopant levels (i.e., $15.2 \mathrm{wt}$ pct) lead to decreased thermal conductivity. ${ }^{[25]}$

Transition metal elements, such as nickel, ${ }^{[8]}$ tantalum, ${ }^{[31,42]}$ and niobium, ${ }^{[31]}$ have been also been used to decrease the thermal conductivity of YSZ. In addition to solid-solution doping, insulating second phase additions, such as $\mathrm{LaPO}_{4}$, have been used to decrease the thermal conductivity of YSZ. ${ }^{[19]}$ Yttria-hafnia and yttria-hafnia-zirconia solid solutions have been shown to have lower thermal conductivities than yttria-zirconia solutions. ${ }^{[2]}$ The beneficial effect of hafnium was 


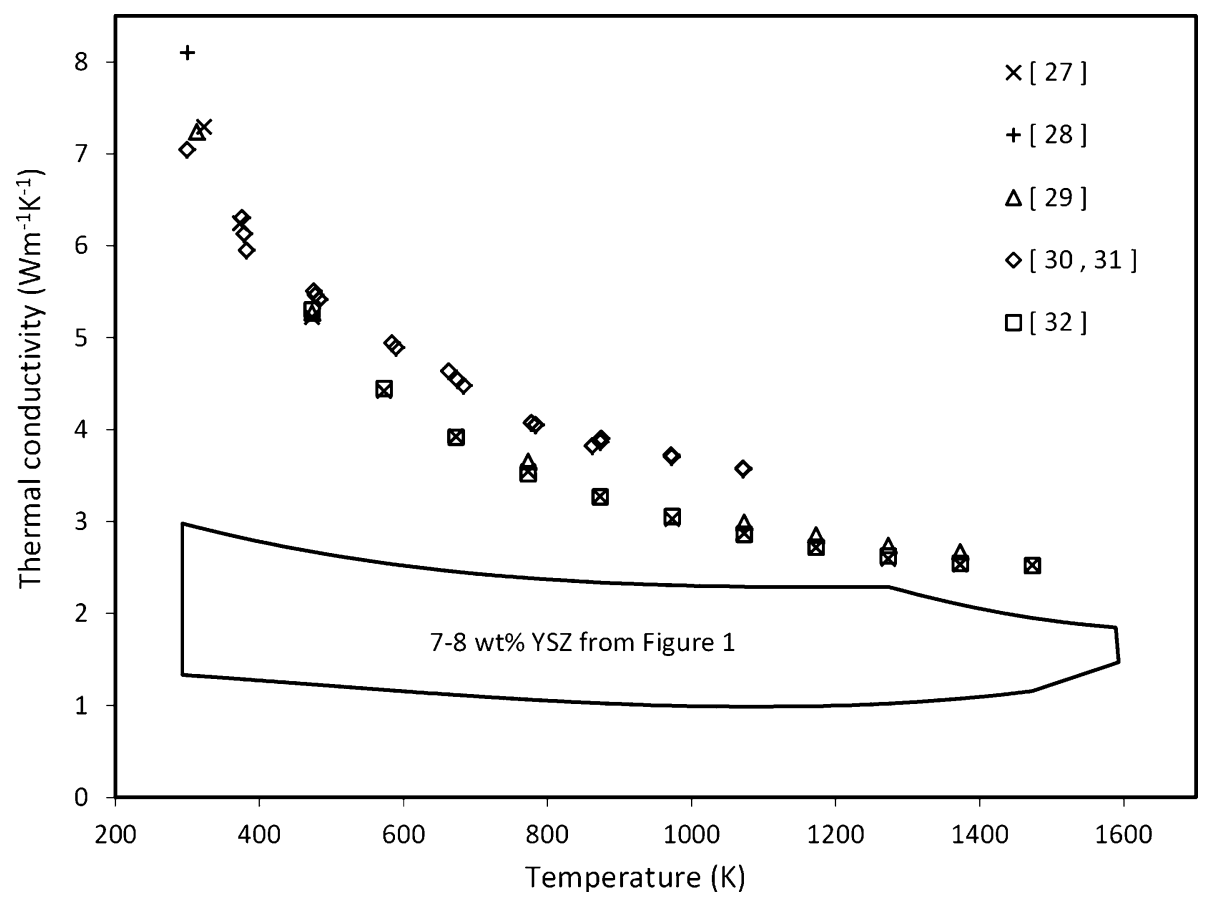

Fig. 2-Thermal conductivity of $\mathrm{ZrO}_{2}{ }^{[27-32]}$

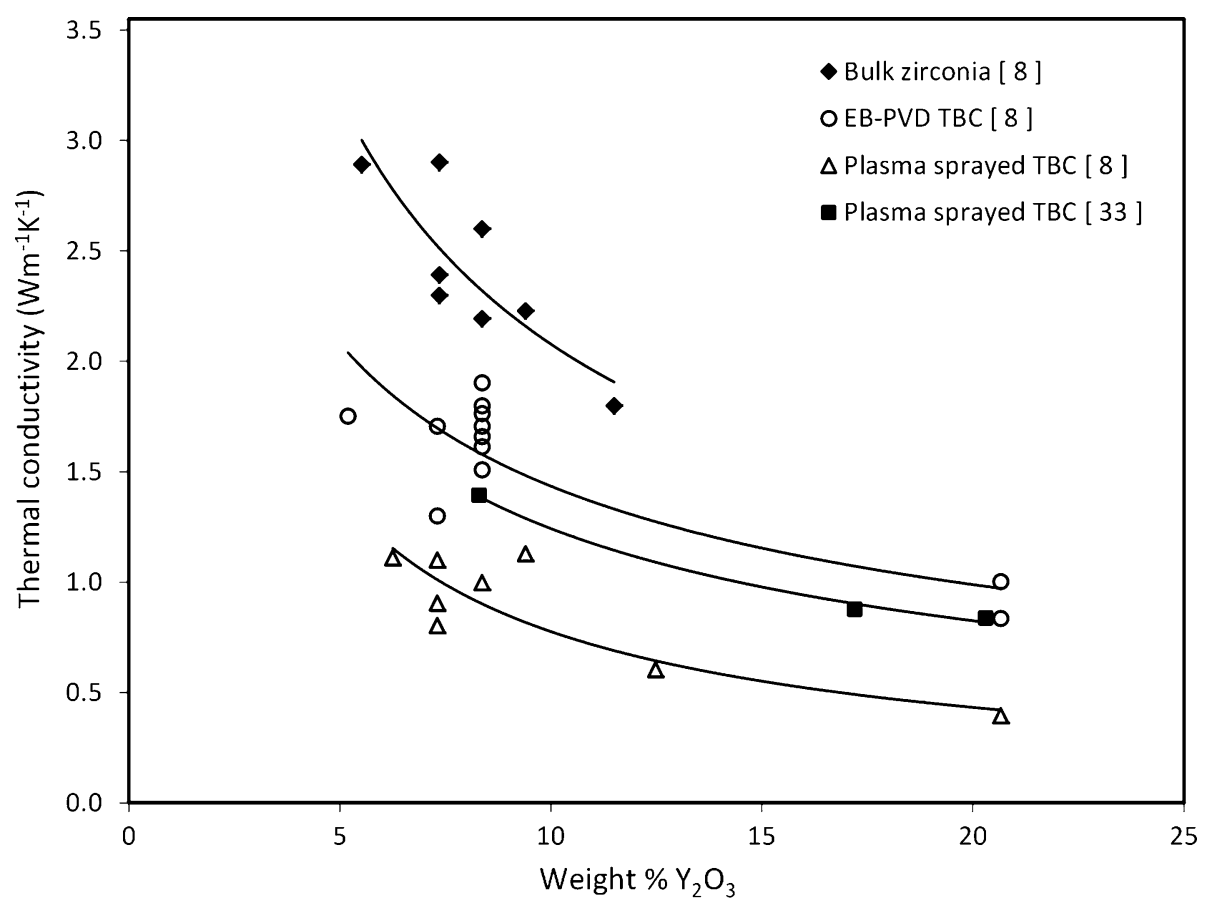

Fig. 3-Effect of yttria content on the thermal conductivity of YSZ. ${ }^{[8,33]}$

attributed to its superior sintering resistance which maintained the desired porous layered microstructure. However, the most promising alternatives to zirconia as thermal barrier coatings are rare-earth oxides that form the pyrochlore crystal structures. ${ }^{[43]}$

The pyrochlore structure is derived from the cubic fluorite structure. ${ }^{[7]}$ The equal number of trivalent and tetravalent ions results in one out of every eight of the oxygen ions in the cubic close packed array to be vacant. The difference between the ionic sizes of the two cations results in ordering of the cations and, consequently, of the oxygen ion vacancies. These ordered defects can scatter phonons and result in low thermal conductivity. The complex structure results in an increase in the 


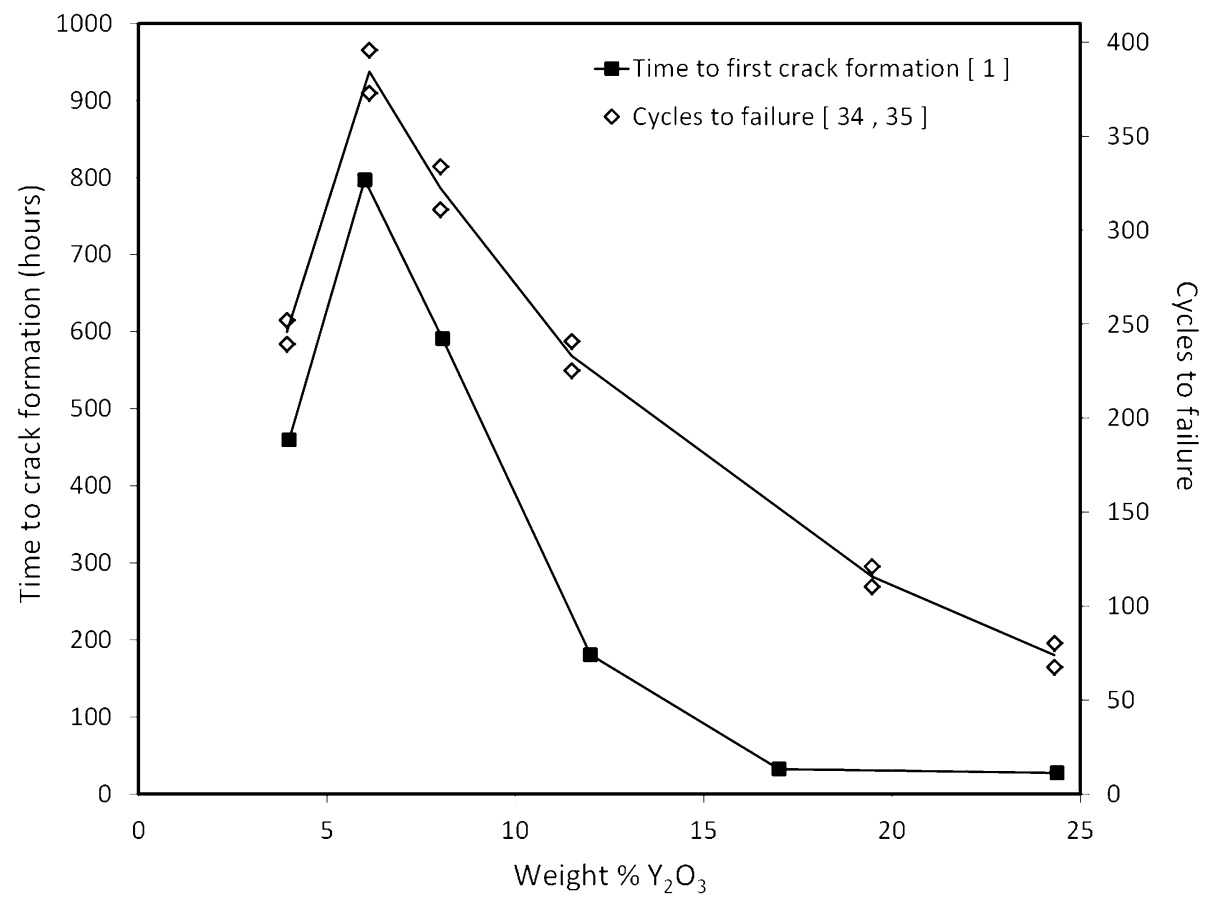

Fig. 4-Effect of yttria content on YSZ coating lifetime..$^{[1,34,35]}$

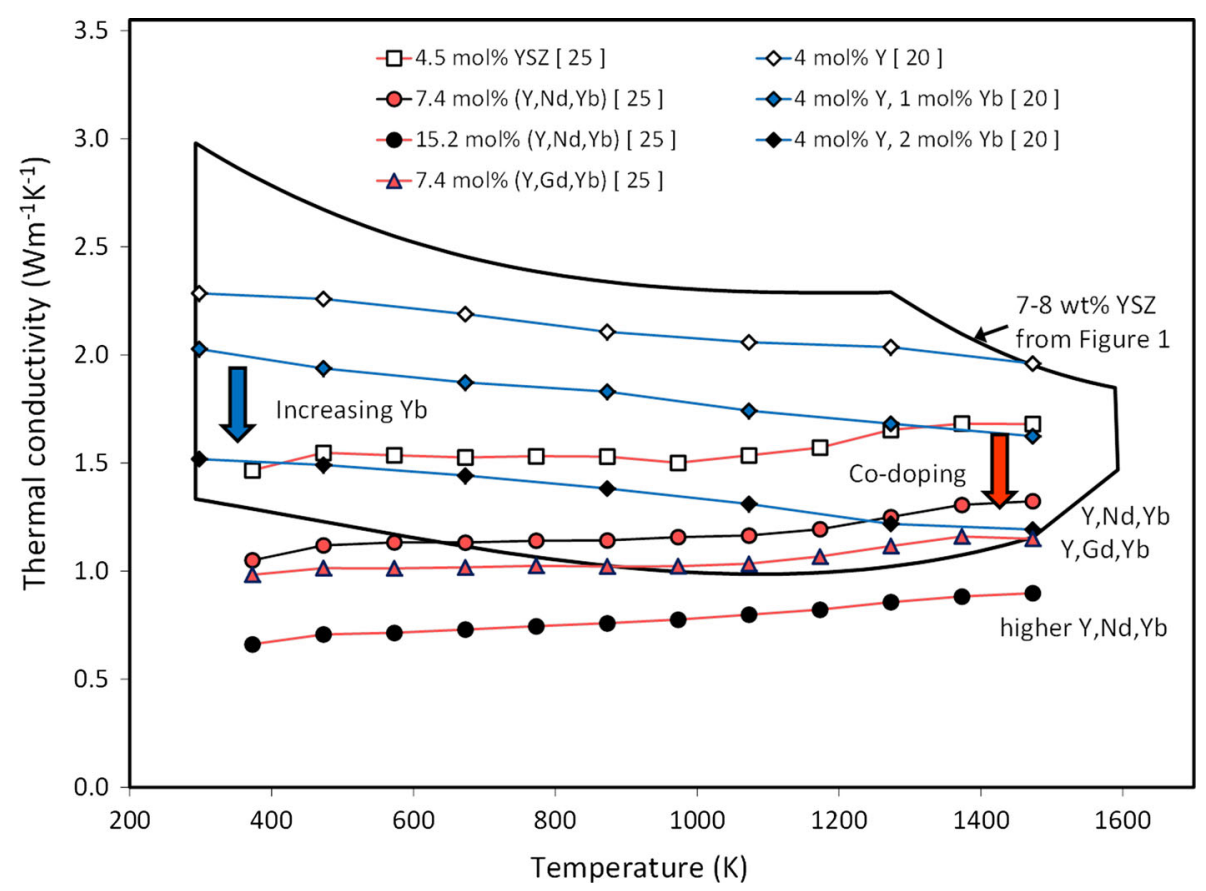

Fig. 5-Effect of ytterbium additions on the thermal conductivity of YSZ. ${ }^{20,25]}$

number of optical phonons that do not contribute to the thermal conduction and increased phonon-phonon interactions, which also decrease the thermal conduction. ${ }^{[7]}$

Thermal conductivities of the pyrochlore $\mathrm{La}_{2} \mathrm{Zr}_{2} \mathrm{O}_{7}$ reported in the literature are shown in Figure $6 .^{[18,44-56]}$ The conductivities vary significantly, but are in the same range as those of YSZ with 7-8 wt pct $\mathrm{Y}_{2} \mathrm{O}_{3}$ from
Figure 1. Some of the reported values are lower than those of YSZ and one report ${ }^{[46]}$ has a very different temperature dependence (i.e., increases strongly with increasing temperature) which was attributed to changes in the microstructure during the measurements.

The thermal conductivities of oxides forming the pyrochlore structure depend on the sizes of the two cations. 


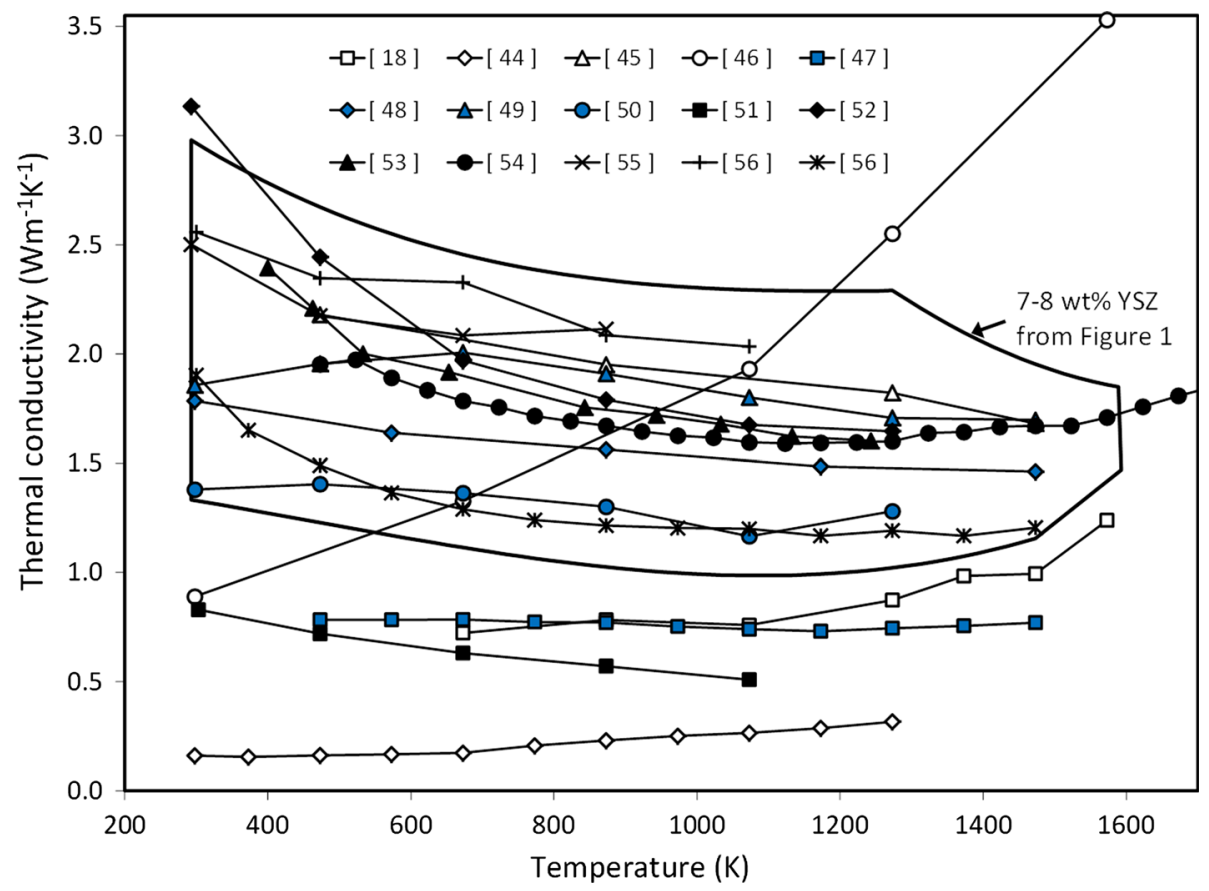

Fig. 6-Thermal conductivity of $\mathrm{La}_{2} \mathrm{Zr}_{2} \mathrm{O}_{7} \cdot{ }^{[18,44-56]}$

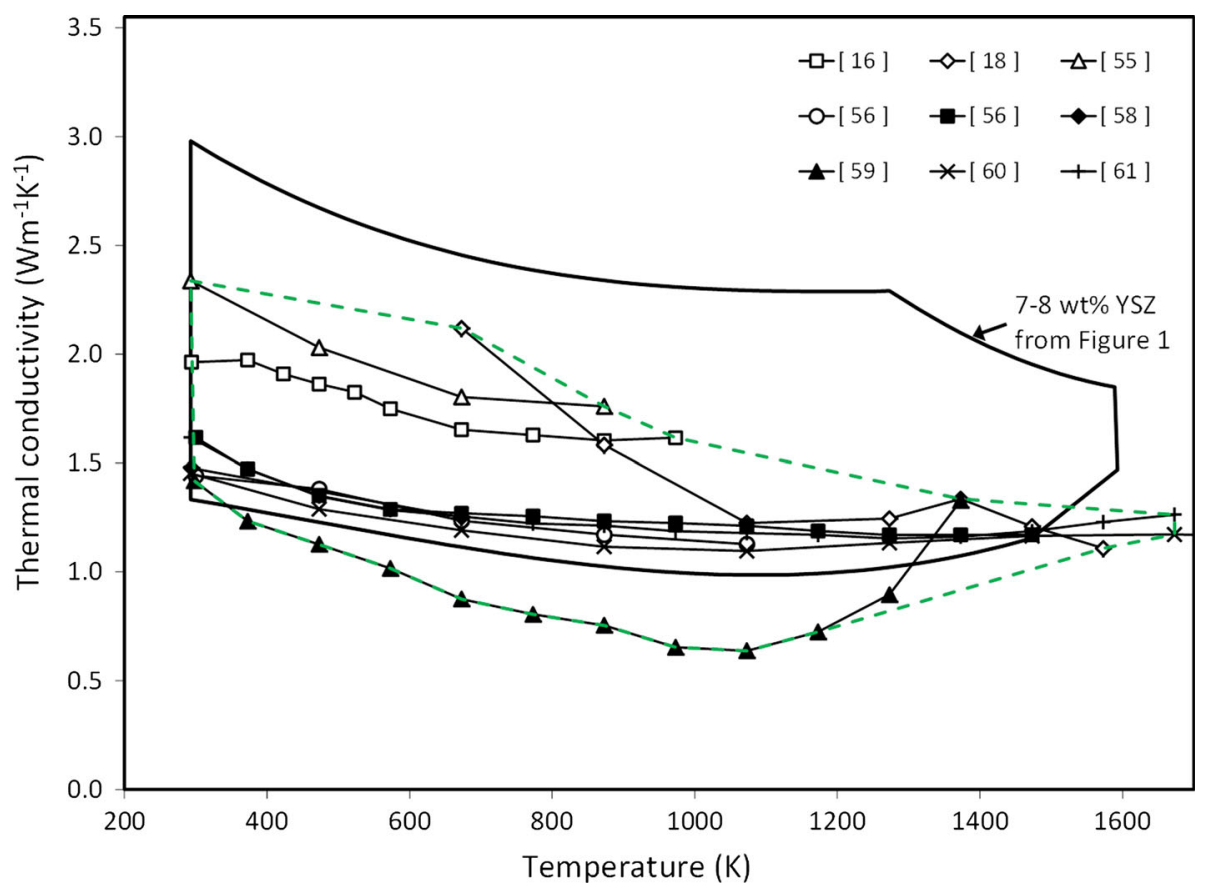

Fig. 7-Thermal conductivity of $\mathrm{Gd}_{2} \mathrm{Zr}_{2} \mathrm{O}_{7}{ }^{[16,18,55,56,58-61]}$

Although the thermal conductivity dependence on the size of the B-site (i.e., $\mathrm{Zr}$ in $\mathrm{Ln}_{2} \mathrm{Zr}_{2} \mathrm{O}_{7}$ ) is stronger, the size of the A-site also has an effect, and simulations predict the lowest thermal conductivities for samarium, europium, and gadolinium on the A-site. ${ }^{[57]}$ Thermal conductivities of pyrochlore zirconates of two of these elements, $\mathrm{Gd}_{2} \mathrm{Zr}_{2} \mathrm{O}_{7}$ and $\mathrm{Sm}_{2} \mathrm{Zr}_{2} \mathrm{O}_{7}$, are shown in Figures $7^{[16,18,55,56,58-61]}$ and $8,{ }^{[16,56,61-67]}$ respectively. The thermal conductivities for these compounds are in the lower range or below those of YSZ with 7-8 wt pet $\mathrm{Y}_{2} \mathrm{O}_{3}$. The conductivities of other rare-earth zirconate pyrochlores including $\mathrm{Nd}_{2} \mathrm{Zr}_{2} \mathrm{O}_{7},{ }^{[16,56,58,68]} \quad \mathrm{Dy}_{2} \mathrm{Zr}_{2} \mathrm{O}_{7},{ }^{[69]} \quad \mathrm{Yb}_{2} \mathrm{Zr}_{2} \mathrm{O}_{7},{ }^{[52,66]}$ 


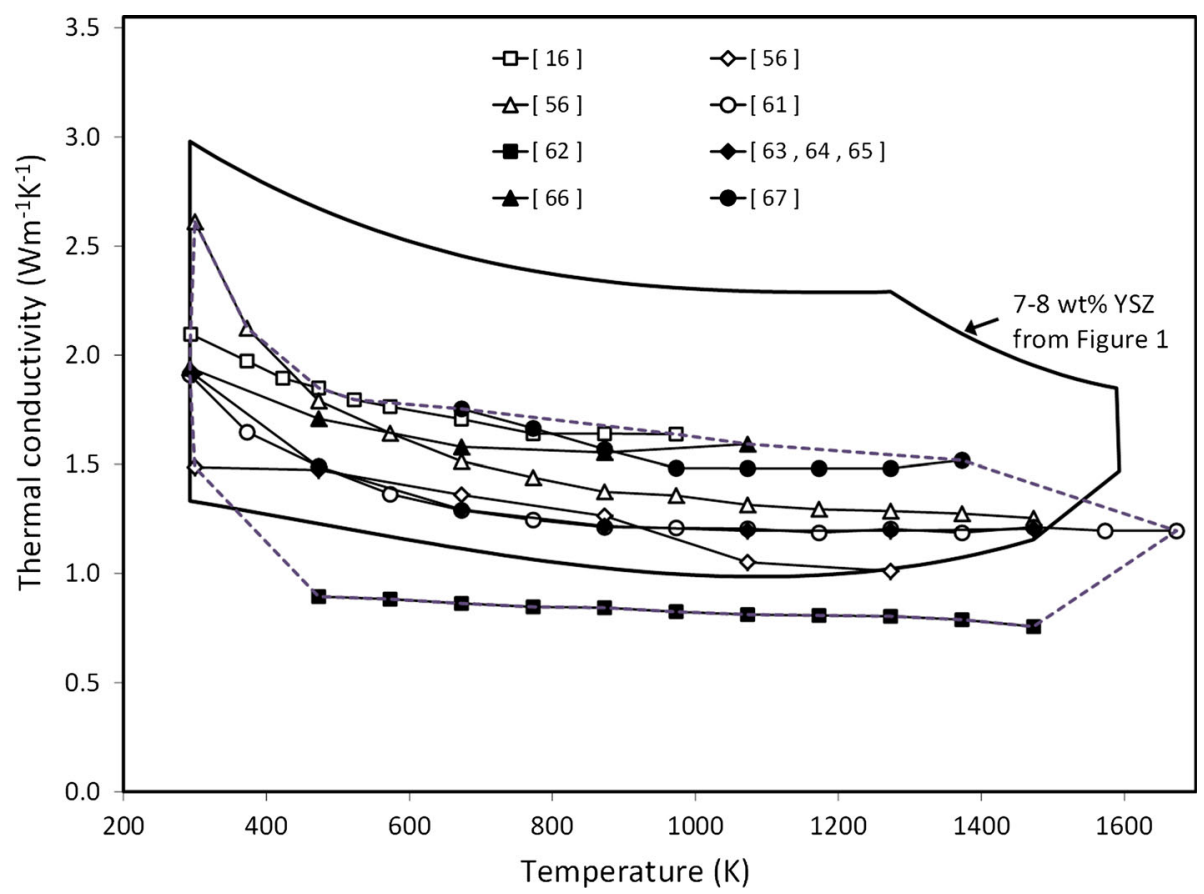

Fig. 8- Thermal conductivity of $\mathrm{Sm}_{2} \mathrm{Zr}_{2} \mathrm{O}_{7} \cdot{ }^{[16,56,61-67]}$

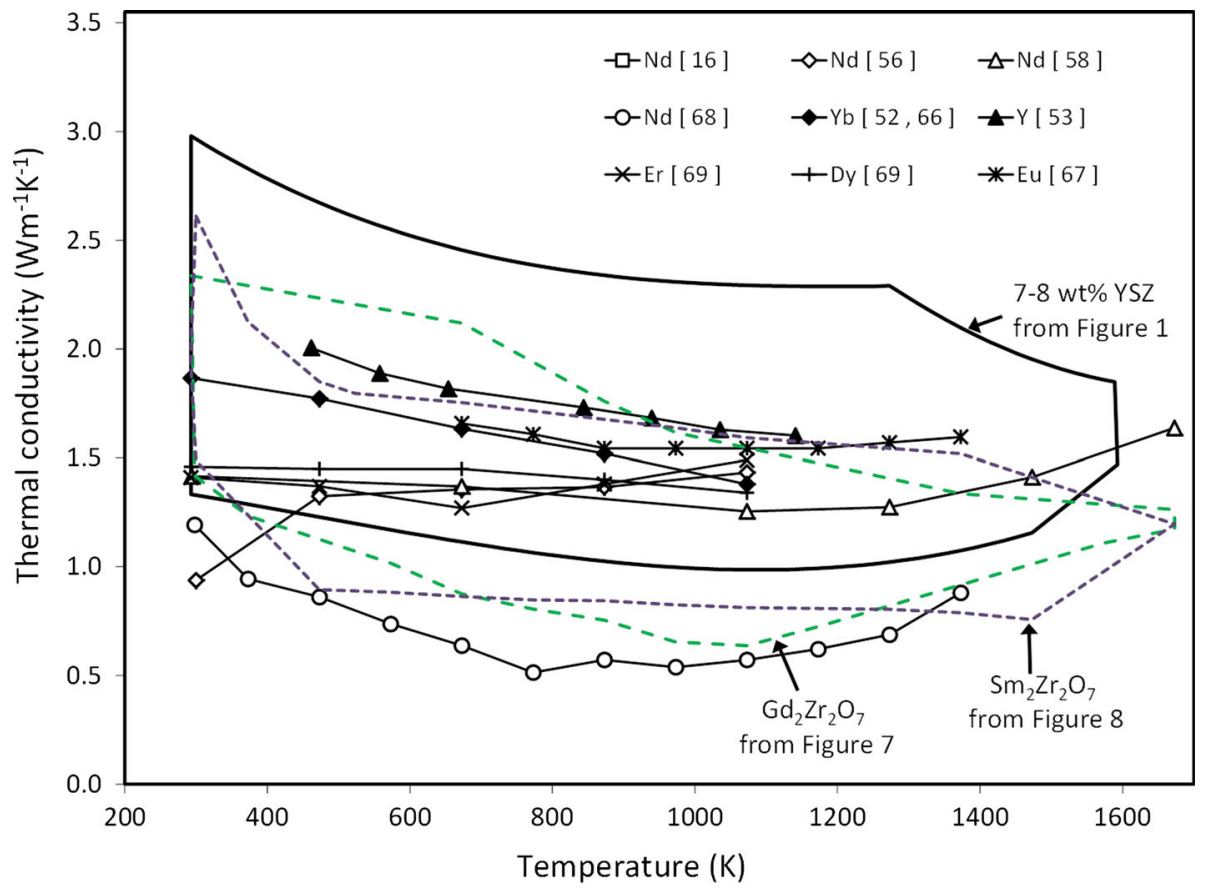

Fig. 9-Thermal conductivity of $\mathrm{Ln}_{2} \mathrm{Zr}_{2} \mathrm{O}_{7}\left(\mathrm{Ln}=\mathrm{Nd}\right.$, Dy, Er, Eu, Y, Yb). ${ }^{[16,52,53,56,58,66-69]}$

$\mathrm{Y}_{2} \mathrm{Zr}_{2} \mathrm{O}_{7},{ }^{[53]} \mathrm{Er}_{2} \mathrm{Zr}_{2} \mathrm{O}_{7},{ }^{[69]}$ and $\mathrm{Eu}_{2} \mathrm{Zr}_{2} \mathrm{O}_{7}{ }^{[67]}$ are similarly in the lower range of the YSZ materials, as shown in Figure 9. $\mathrm{Gd}_{2} \mathrm{Zr}_{2} \mathrm{O}_{7}$ and $\mathrm{Sm}_{2} \mathrm{Zr}_{2} \mathrm{O}_{7}$ have received the most attention as candidate thermal barrier coating materials due to their good combination of thermal and mechanical properties. ${ }^{[7]}$

As with zirconia, doping can be used to create defects which increase phonon scattering and thus decrease the thermal conductivity of pyrochlore phases. For example, $\mathrm{La}_{2} \mathrm{Zr}_{2} \mathrm{O}_{7}$ has been doped with a variety of rare-earth oxides, including oxides of yttrium, ${ }^{[32,53]}$ ytterbium, ${ }^{[52]}$ neodymium, ${ }^{58]}$ samarium, ${ }^{[6]}$ dysprosium, ${ }^{[51,58]}$ and europium, ${ }^{[58]}$ to decrease the thermal conductivity. Similarly, the thermal conductivity of $\mathrm{Gd}_{2} \mathrm{Zr}_{2} \mathrm{O}_{7}$ has been reduced with additions of yttrium, ${ }^{[70]}$ ytterbium, ${ }^{[60]}$ and neodymium. ${ }^{[71]}$ Two examples of the beneficial effect of doping, yttrium 


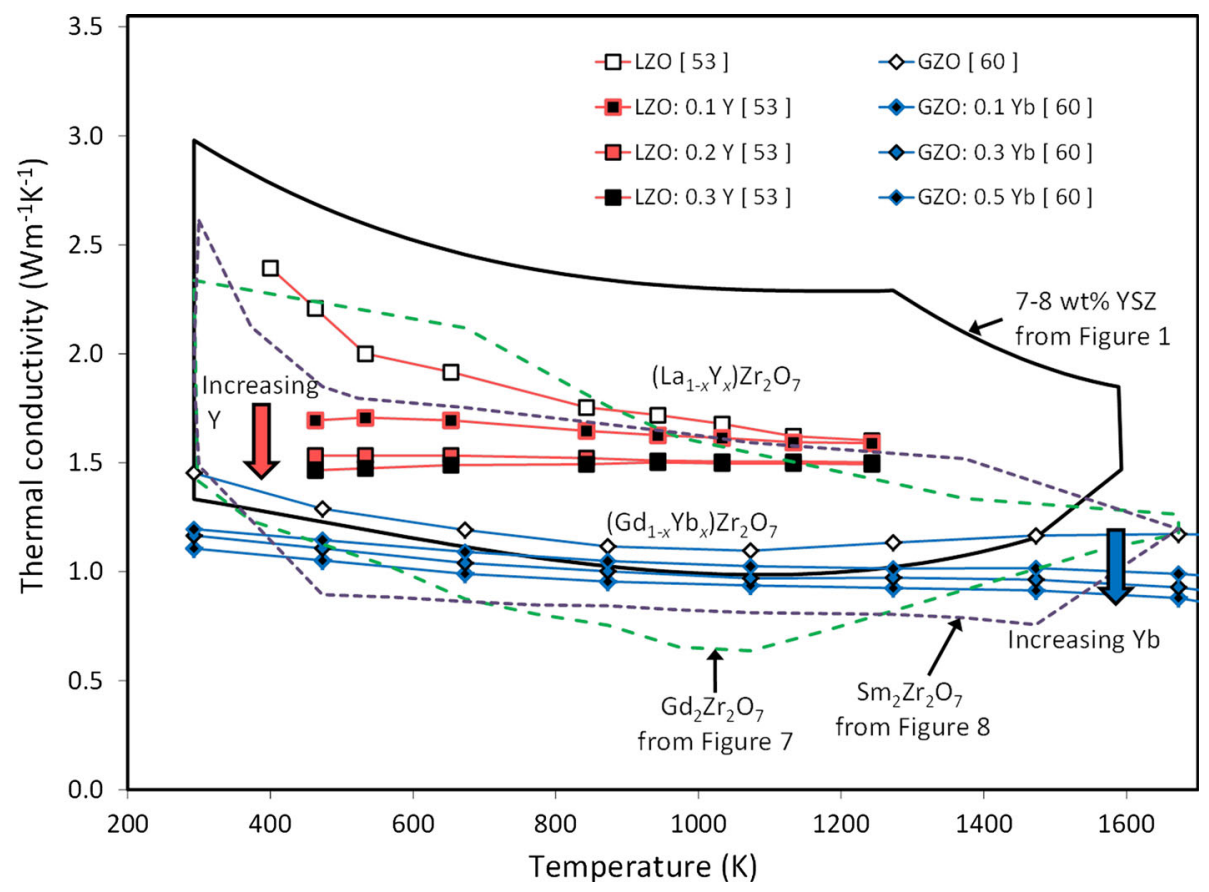

Fig. 10-Effect of doping pyrochlore zirconates on thermal conductivity. ${ }^{[53,60]}$

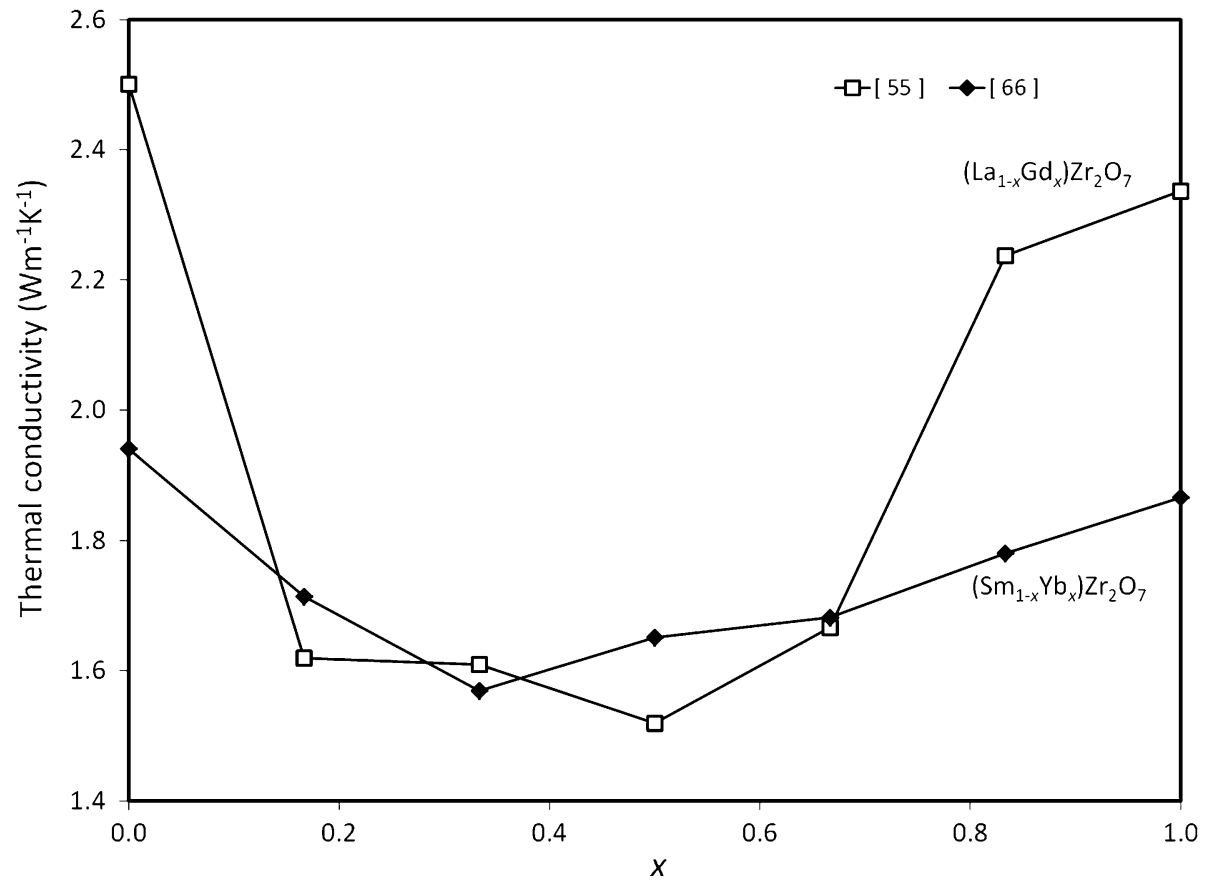

Fig. 11-Thermal conductivity of mixed lanthanide perovskites. ${ }^{[5,66]}$

doping of $\mathrm{La}_{2} \mathrm{Zr}_{2} \mathrm{O}_{7}$ and ytterbium doping of $\mathrm{Gd}_{2} \mathrm{Zr}_{2} \mathrm{O}_{7}$, are shown in Figure 10. ${ }^{[53,60]}$ Because of the structural similarities among the lanthanide zirconates, solid solutions between lanthanide zirconates can be formed and provide lower thermal conductivities. The thermal conductivities of two of these solutions, $\left(\mathrm{La}_{1-x} \mathrm{Gd}_{x}\right)_{2}$ $\mathrm{Zr}_{2} \mathrm{O}_{7}{ }^{[55]}$ and $\left(\mathrm{Sm}_{1-x} \mathrm{Yb}_{x}\right)_{2} \mathrm{Zr}_{2} \mathrm{O}_{7},{ }^{[66]}$ are shown in
Figure 11. In both cases, the minimum thermal conductivities are in the middle composition range. The minimum thermal conductivity for $\left(\mathrm{Sm}_{1-x} \mathrm{Yb}_{x}\right)_{2} \mathrm{Zr}_{2} \mathrm{O}_{7}$ is at about $x \sim 1 / 3$ and was attributed to lattice softening associated with disordering of the structure. ${ }^{[66]}$

Dopants can also occupy the zirconium site in lanthanide zirconates. For example, $\mathrm{La}_{2} \mathrm{Zr}_{2} \mathrm{O}_{7}$ has been 


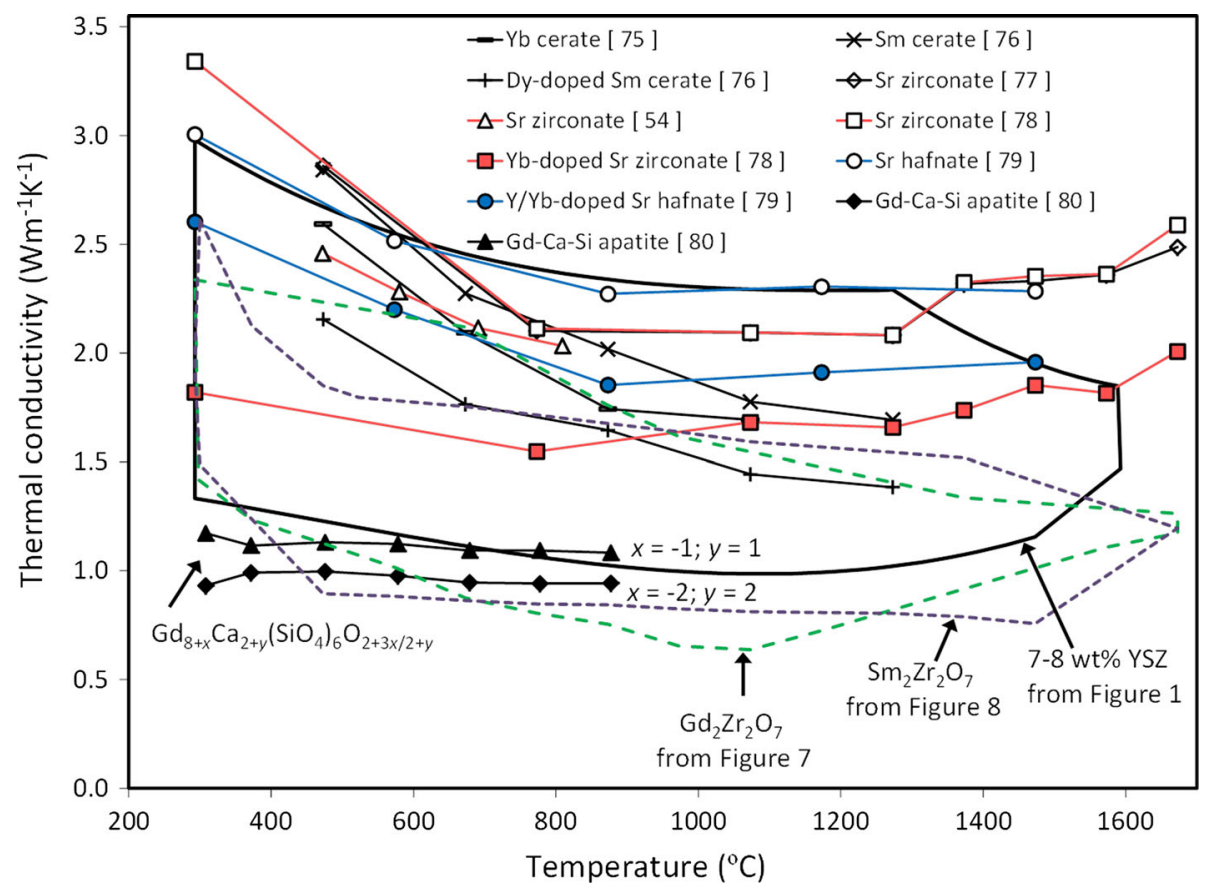

Fig. 12-Thermal conductivity of other oxides. ${ }^{[54,75-80]}$

doped with cerium on the zirconium site alone ${ }^{[49-51,72,73]}$ or as a co-dopant with ytterbium, ${ }^{[48]}$ samarium, ${ }^{[65]}$ or dysprosium + neodymium $^{[51]}$ on the lanthanide site to decrease the thermal conductivity. However, cerium additions to $\mathrm{Sm}_{2} \mathrm{Zr}_{2} \mathrm{O}_{7}$ have been shown to lead to an increase in thermal conductivity. ${ }^{[63,64]}$ Titanium can also be doped on the zirconium site either alone or with simultaneous doping of neodymium on the gadolinium site ${ }^{[71]}$ to increase the thermal conductivity of $\mathrm{Gd}_{2} \mathrm{Zr}_{2} \mathrm{O}_{7}$.

The distortion of the $\mathrm{AO}_{8}$ dodecahedron provides an additional opportunity for decreasing the thermal conductivity using the "rattling" of dopants. ${ }^{[32]}$ In this mechanism, weakly bonded dopant atoms undergo low frequency vibrations that disrupt lattice phonons. ${ }^{[74]}$ Decreases in the thermal conductivity of $\mathrm{La}_{2} \mathrm{Zr}_{2} \mathrm{O}_{7}$ due to indium, ${ }^{[32]}$ scandium, ${ }^{[32]}$ and ytterbium ${ }^{[52]}$ additions have been attributed to rattling of the dopant ion.

The thermal conductivity of some other oxides that have been evaluated for use as thermal barrier coatings are shown in Figure 12. ${ }^{[54,75-80]}$ The lanthanide cerates have thermal conductivities in the upper range of those of YSZ and higher than those of the lanthanide zirconates, ${ }^{[75,76]}$ but can be decreased with doping (e.g., $\left.\left(\mathrm{Sm}_{1-x} \mathrm{Dy}_{x}\right)_{2} \mathrm{Ce}_{2} \mathrm{O}_{7}\right) .^{[76]}$ The thermal conductivity of $\mathrm{La}_{2} \mathrm{Hf}_{2} \mathrm{O}_{7}$, however, is lower than that of $\mathrm{La}_{2} \mathrm{Zr}_{2} \mathrm{O}_{7}$, which has been attributed to reduction in the phonon velocity due to the lower elastic modulus of $\mathrm{La}_{2} \mathrm{Hf}_{2} \mathrm{O}_{7}{ }^{\left[{ }^{[81]}\right.}$ The thermal conductivities of strontium zirconate ${ }^{[54,77,78]}$ and strontium hafnate ${ }^{[79]}$ are in a similar range (i.e., upper range of YSZ), but can be decreased by creating defects with yttrium and ytterbium doping.

The thermal conductivities of the apatite, $\mathrm{Gd}_{8+x} \mathrm{Ca}_{2+y}\left(\mathrm{SiO}_{4}\right)_{6} \mathrm{O}_{2+3 x / 2+y}$, are lower than that of YSZ ${ }^{[80]}$ The apatite structure can be doped to form oxygen vacancies, cation vacancies or oxygen interstitials. Oxygen interstitials were shown to not significantly affect the thermal conductivity, but both cation and oxygen vacancies did lead to decreases in the thermal conductivity, and the lowest conductivity was observed for the highest oxygen vacancy concentration.

One of the reasons for the wide variations in thermal conductivities between different reports is the differences in the microstructures and morphologies. Increased porosity decreases the thermal conductivity of YSZ as shown in Figure 13..$^{[21,25,30]}$ The lines in Figure 13 represent the thermal conductivity being proportional to the volume fraction of solid to the $3 / 2$ power using a model based on a continuous solid phase and assuming that the thermal conductivity of the pores is much smaller than that of the solid. ${ }^{[82]}$ In addition to the amount of porosity, the morphology can be used to control transport properties. ${ }^{[83]}$ This can include the size and shape of the morphological features. Figure 14 shows two examples in which finer morphological features results in decreased thermal conductivity. ${ }^{[14,23]}$

Changes in microstructures during heat treatment or operation can cause coarsening of the microstructure, which can lead to increases in the thermal conductivity of the coating. Increases in the thermal conductivity after heat treatment or high temperature use of zirconiabased materials ${ }^{[22,38,62,84]}$ and pyrochlores ${ }^{[15,47,62]}$ have been reported. For example, the increases in the thermal conductivities of the materials shown in Figure 14 after various heat treatments are shown in Figure $15 .{ }^{[14,23]} \mathrm{A}$ detailed discussion of the effects of microstructure and changes in microstructure, as well as the degradation mechanisms discussed in the following sections, can be found in a recent review. ${ }^{[1]}$ 


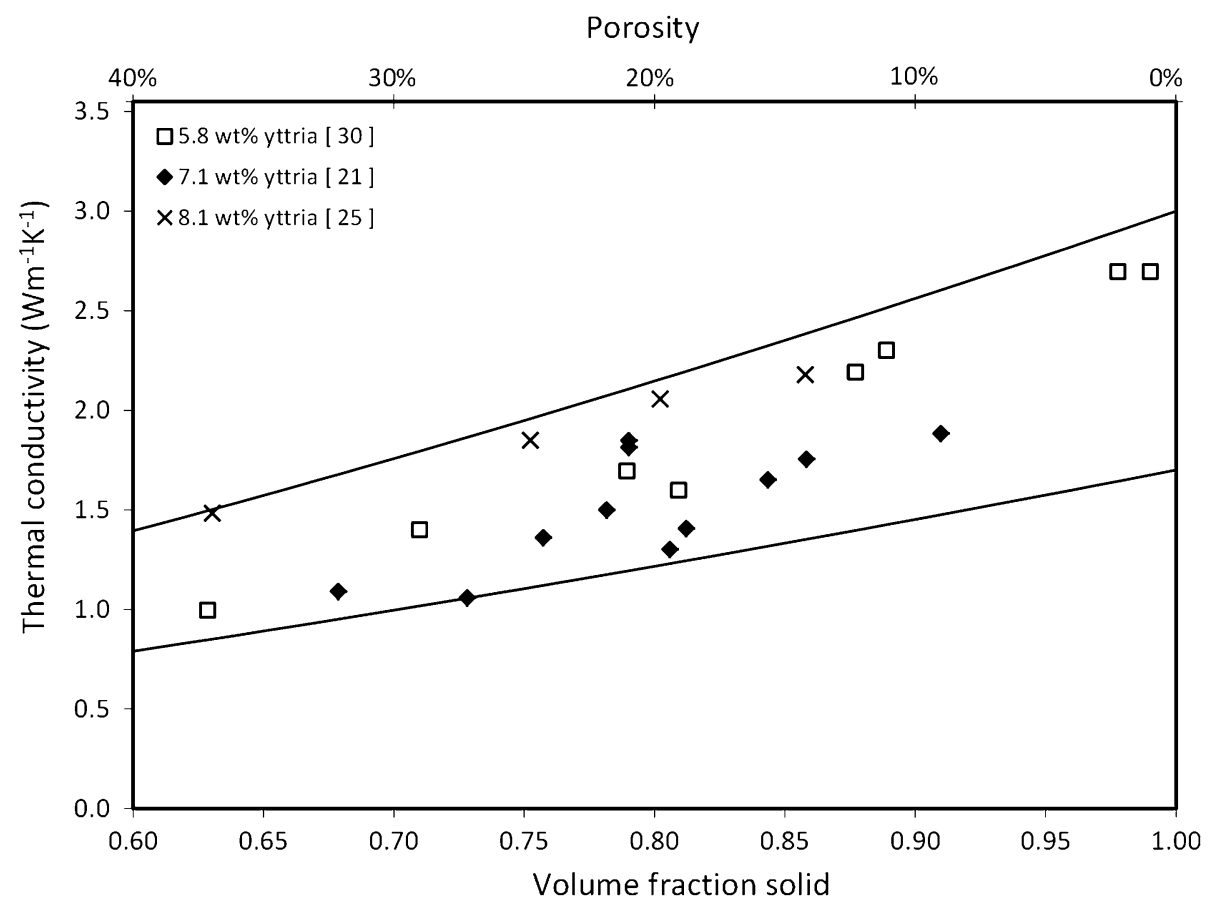

Fig. 13-Effect of porosity on thermal conductivity. ${ }^{[21,25,30]}$

\section{STABILITY}

During high temperature operation the desired tetragonal $t^{\prime}$ phase in zirconia-based thermal barrier coatings can transform to the more stable monoclinic phase. ${ }^{[85-87]}$ The transformation of the $t^{\prime}$ phase has been shown to occur by the formation of a two-phase lamellar microstructure with high-yttria-content and low-yttria-content phases, which then transform to the monoclinic phase. ${ }^{[88]}$ The $t^{\prime}$ phase can be stabilized using dopants such as magnesium, ${ }^{[89]}$ ytterbium, ${ }^{[90]}$ and gadolinium. ${ }^{[41]}$ The decomposition of the $t^{\prime}$ phase at high temperatures limits the maximum operating temperature of the coating. ${ }^{[91-93]}$

In addition to changes in the ceramic thermal barrier coating, changes in the other coatings in the thermal barrier system can occur, so the lifetime of the coating depends on the compositions and geometries of all system components. ${ }^{[35]}$ Thus, models for predicting thermal barrier coating lifetimes need to include factors such as growth of the thermally grown oxide (TGO) on the alloy and sintering of the ceramic thermal barrier coating. ${ }^{[94,95]}$ The microstructure of the coating can be used to improve the cycling resistance by improving the fracture toughness of the coating, ${ }^{[96]}$ reducing the defects $^{[17]}$ or reducing the stress levels. ${ }^{[97]}$ However, changes in the microstructure during operation can lead to degradation.

One such change is sintering of the ceramic thermal barrier coating. As noted above, this sintering can lead to an increase in the thermal conductivity. In addition, sintering can cause an increase in the stiffness of the coating, which increases the stresses and can lead to cracking. ${ }^{[98-100]}$ The amount of sintering in YSZ thermal barrier coatings can be reduced by additions of $\mathrm{La}_{2} \mathrm{Zr}_{2} \mathrm{O}_{7}{ }^{[101]}$
During operation, the thickness of the TGO increases. Undulations in the TGO layer generate locally high stress levels, which can lead to failure at the interface between the TGO and the thermal barrier coating. ${ }^{[102-108]}$ Grit blasting of the alloy prior to coating deposition has been shown to lead to a more planar TGO and thus improved lifetime. ${ }^{[109]}$ However, the failure in this location highlights the importance of compatibility of the thermal barrier coating material with the substrate alloy.

As shown above in Figure 4, small amounts of yttria additions increase the cycle life of YSZ thermal barrier coatings, but larger amounts degrade the cycle life. ${ }^{[1,34,35]}$ A similar maximum in cycle life has been reported with other dopants including ytterbium, neodymium, gadolinium, and samarium. ${ }^{[33]}$ The co-dopants can increase cycle life relative to YSZ (i.e., only yttrium doping) for high total dopant levels. Dysprosium-doped zirconia has been shown to have a better cycling lifetime than YSZ, but not as high as $\mathrm{Gd}_{2} \mathrm{Zr}_{2} \mathrm{O}_{7} .^{[110]}$ Sintering can also occur in the lanthanide zirconate coatings during use. Yttria ${ }^{[111]}$ and neodymium ${ }^{[112]}$ doping have been shown to reduce the amount of sintering. Hafniabased coatings have also been shown to have good resistance to sintering. ${ }^{[13]}$ Thus, microstructural stability is important for both the mechanical and thermal performance of the thermal barrier coating.

\section{CORROSION}

The lifetimes of thermal barrier coatings can be decreased due to the formation of calcium magnesium aluminosilicate (CMAS) deposits from debris injected into the engine. ${ }^{[91]}$ The reaction of YSZ with CMAS can result in depletion of yttrium from YSZ, which can lead 


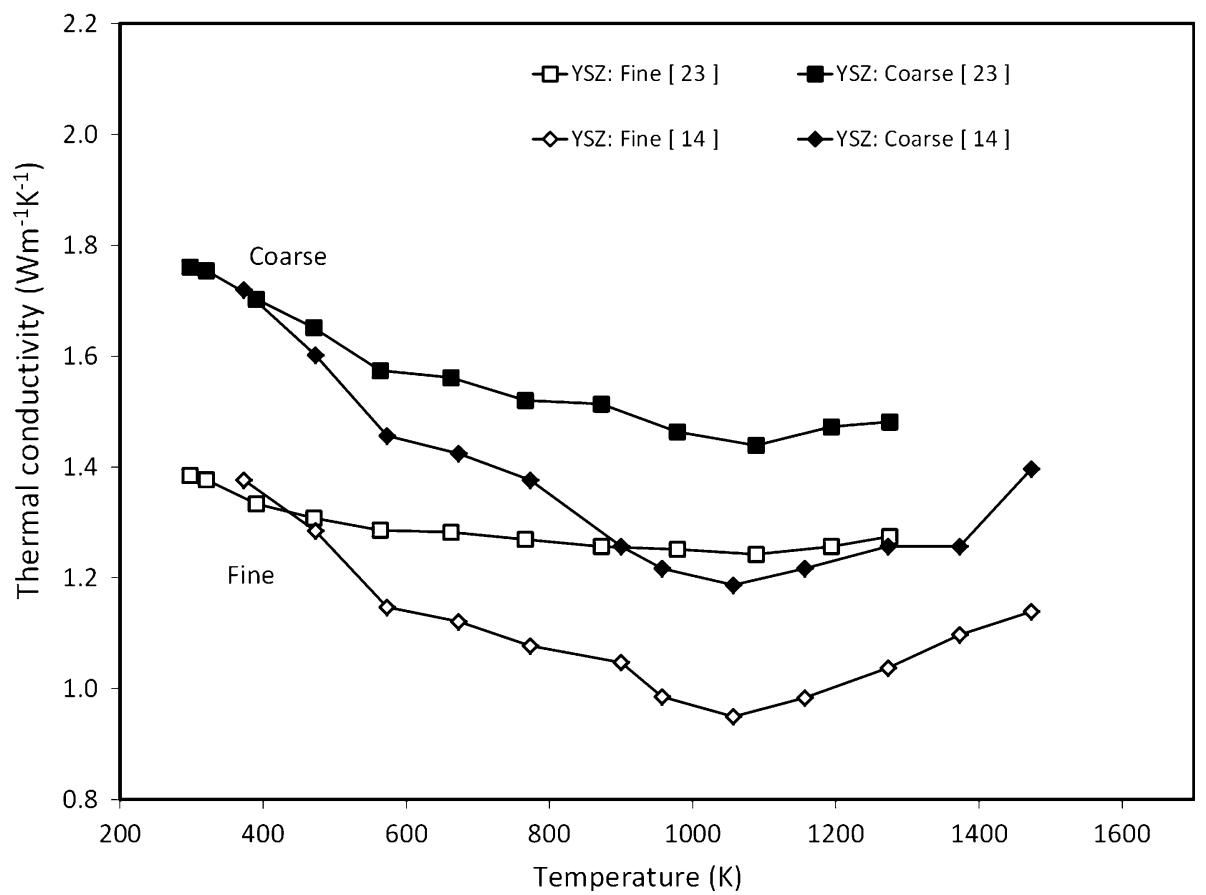

Fig. 14 -Effect of microstructure on thermal conductivity. ${ }^{[14,23]}$

to destabilization of the $t^{\prime}$ phase. ${ }^{[114-121]}$ The destabilization occurs as the zirconia is dissolved and reprecipitated in the monoclinic crystal structure. ${ }^{[91,116]}$ Similarly, destabilization of the $t^{\prime}$ phase has been observed in the reaction of YSZ with calcium aluminosilicates, ${ }^{[122]}$ artificial volcanic ash, ${ }^{[123]}$ metallurgical slags, ${ }^{[124]}$ and $\mathrm{V}_{2} \mathrm{O}_{5}-\mathrm{Na}_{2} \mathrm{SO}_{4}{ }^{[125]}$

In addition to destabilization of the $t^{\prime}$ phase, CMAS penetration into YSZ coating can stiffen the surface layer, which increases the stress and leads to delamination within the coating..$^{[115,120,126-131]}$ CMAS penetration can also increase the coefficient of thermal expansion near the surface which will lead to an increase in the strain energy during thermal cycling. ${ }^{[132-135]}$ To mitigate the degradation of YSZ coatings in CMAS and similar corrosive conditions, environmental barrier coatings have been developed.

One approach to reducing CMAS attack is with the addition of an alumina or aluminum-containing layer. ${ }^{[18,136-140]}$ The beneficial effect of aluminum has been attributed to increased crystallization of the deposit, which reduces penetration of the CMAS into the coating. Titanium additions are also beneficial as nucleating agents to promote crystallization in the deposit. ${ }^{[136]}$ Silica additions have been shown to decrease wettability and thus reduce CMAS penetration. ${ }^{[140]}$ Other silicon-containing layers, including Mo-Si- $\mathrm{B}^{[141]}$ and ytterbium or yttrium silicates ${ }^{[142]}$ have been used to promote the formation of crystalline phases and reduce degradation in CMAS. A mixture of $\mathrm{Y}_{2} \mathrm{O}_{3}$ and $\mathrm{ZrO}_{2}$ has been shown to have better resistance to CMAS attack than either $\mathrm{ZrO}_{2}$ or $\mathrm{Y}_{2} \mathrm{O}_{3} \cdot{ }^{[143]}$ The superior performance of the mixed oxide coatings was attributed to the formation of an oxyapatite crystalline phase that limited CMAS penetration into the coating.

Similarly, the penetration of CMAS into $\mathrm{Y}_{2} \mathrm{Zr}_{2} \mathrm{O}_{7}$ pyrochlore has been shown to be less than that in YSZ ${ }^{[144]}$ The CMAS resistance of other lanthanide pyrochlore phases including $\mathrm{La}_{2} \mathrm{Zr}_{2} \mathrm{O}_{7},{ }^{[145,146]}$ $\mathrm{Gd}_{2} \mathrm{Zr}_{2} \mathrm{O}_{7},{ }^{[119,144,147,148]}$ and $\mathrm{Yb}_{2} \mathrm{Zr}_{2} \mathrm{O}_{7}{ }^{[144]}$ have also been shown to be better than that of YSZ. $\mathrm{Gd}_{2} \mathrm{Zr}_{2} \mathrm{O}_{7}$ is also more resistant to attack by $\mathrm{V}_{2} \mathrm{O}_{5}-\mathrm{Na}_{2} \mathrm{SO}_{4}$ as compared to YSZ. ${ }^{[149]}$ Although the pyrochlore phases provide improved resistance to CMAS attack, they can react with alumina to form aluminate phases, ${ }^{[150,151]}$ so an intermediate YSZ layer between the pyrochlore and the TGO formed on the alloy improves stability. This YSZ interlayer has an added benefit of decreasing the difference in the coefficients of thermal expansion, and thus the associated stresses, at the interface. ${ }^{[152-154]}$

Thus, a duplex thermal barrier coatings with an outer layer of a rare-earth zirconate pyrochlore and an inner YSZ layer is an attractive approach for improving CMAS resistance. The thermal conductivity of such a YSZ $+\mathrm{La}_{2} \mathrm{Zr}_{2} \mathrm{O}_{7}$ duplex coating is between the thermal conductivity of the individual materials as would be expected. ${ }^{[18]}$ However, in another report, the thermal conductivity of $\mathrm{YSZ}+\mathrm{Nd}_{2} \mathrm{Zr}_{2} \mathrm{O}_{7}$ was reported to be lower than either of the individual layers. ${ }^{[68]}$ This unexpected result was attributed to differences in the microstructure and interface structure. The outer pyrochlore layer in a duplex coating can reduce the amount of CMAS penetration. ${ }^{[145,146]}$ Compatibility at the $\mathrm{La}_{2} \mathrm{Zr}_{2} \mathrm{O}_{7} / \mathrm{YSZ}$ interface can be improved by having a mixed two-phase region at the interfaces ${ }^{[145,146]}$ or by doping the $\mathrm{La}_{2} \mathrm{Zr}_{2} \mathrm{O}_{7}$ with cerium to provide a better match in the coefficients of thermal expansion. ${ }^{[155]} \mathrm{A}$ 


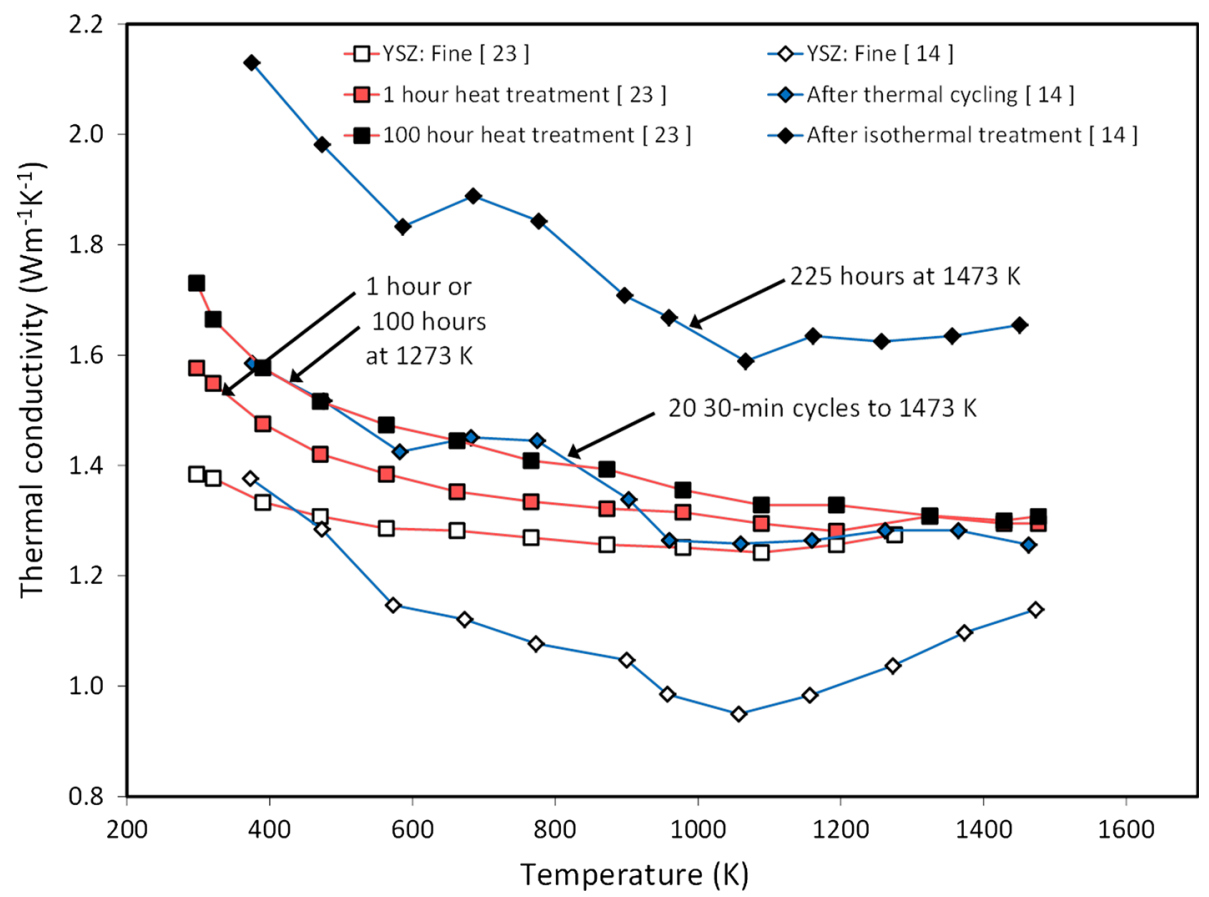

Fig. 15-Effect of heat treatment on thermal conductivity. ${ }^{[14,23]}$

$\mathrm{La}_{2} \mathrm{Zr}_{2} \mathrm{O}_{7}+\mathrm{YSZ}$ duplex coating has also been shown to have better thermal shock resistance than a YSZ coating. ${ }^{\left[{ }^{[7]}\right.}$ Similarly, a $\mathrm{La}_{2} \mathrm{Ce}_{2} \mathrm{O}_{7}+$ YSZ duplex coating has been shown to have better cycling life than a YSZ coating. ${ }^{[156]}$

The use of a duplex coating decreases the temperature of the intermediate YSZ layer for a given operating temperature, which improves the stability of the $t^{\prime}$ phase and thus increases the high temperature limit of the coating system. ${ }^{[157]}$ However, duplex coatings are not always superior to single-layer coatings. For example, a $\mathrm{Sm}_{2} \mathrm{Zr}_{2} \mathrm{O}_{7}+$ YSZ duplex coating was shown to have cycling resistance that was better than a single-layer $\mathrm{Sm}_{2} \mathrm{Zr}_{2} \mathrm{O}_{7}$ coating but was slightly worse than a YSZ coating. ${ }^{158]}$ Similarly, a single-layer $\mathrm{Gd}_{2} \mathrm{Zr}_{2} \mathrm{O}_{7}$ coating was shown to have longer cycling life than a duplex $\mathrm{Gd}_{2} \mathrm{Zr}_{2} \mathrm{O}_{7}+$ YSC coating. ${ }^{[110]}$ However, these latter two examples were not in the presence of CMAS, which is the environment in which the pyrochlore zirconate phases have a particular advantage.

\section{CONCLUSIONS}

Lanthanide zirconate compounds forming the pyrochlore crystal structure offer advantages over YSZ including lower thermal conductivity and improved chemical stability - especially in the presence of molten oxides, such as CMAS. However, because of the superior compatibility of zirconia with the oxide formed on the turbine blade alloy, the combination of two materials in a duplex coating is a promising approach. This combination of the two coating materials complicates an already complicated multilayer system. In addition, the properties of each layer, and the interfaces between layers, depend critically on the microstructures and the stability of those microstructures. Thus, the design and fabrication of thermal barrier coating systems for increasing the operation temperature (i.e., higher efficiency) and extending the lifetime (i.e., lower cost) of gas turbine engines is a significant challenge, but new materials and processes are being developed to meet this important challenge.

\section{ACKNOWLEDGMENTS}

This material is based upon work supported by the Department of Energy under Award Number DE-FE0011245. This report was prepared as an account of work sponsored by an agency of the United States Government.

\section{DISCLAIMER}

Neither the United States Government nor any agency thereof, nor any of their employees, makes any warranty, express or implied, or assumes any legal liability of responsibility for the accuracy, completeness, or usefulness of any information, apparatus, product, or process disclosed, or represents that its use would not infringe privately owned rights. Reference herein to any specific commercial product, process, or service by trade name, trademark, manufacturer, or otherwise does not necessarily constitute or imply its endorsement, recommendation, or favoring by the United States Government or any agency thereof. The views 
and opinions of the author expressed herein do not necessarily state or reflect those of the United States Government or any agency thereof.

\section{REFERENCES}

1. R. Darolia: Int. Mater. Rev., 2013, vol. 58, pp. 315-48.

2. N.P. Padture, M. Gell, and E.H. Jordan: Science, 2002, vol. 296, pp. $280-84$.

3. D.R. Clarke, M. Oechsner, and N.P. Padture: MRS Bull., 2012, vol. 37, pp. 891-98.

4. T.M. Pollock, D.M. Lipkin, and K.J. Hemker: MRS Bull., 2012, vol. 37, pp. 923-31

5. D.R. Clarke: Surf. Coat. Technol., 2003, vols. 163-164, pp. 64-74.

6. C.G. Levi: Curr. Opin. Solid State Mater. Sci., 2004, vol. 6, pp. 77-91.

7. W. Pan, S.R. Phillpot, C. Wan, A. Chernatynskiy, and Z. Qu: MRS Bull., 2012, vol. 37, pp. 917-22.

8. J.R. Nicholls, K.J. Lawson, A. Johnstone, and D.S. Rickerby: Surf. Coat. Technol., 2002, vols. 151-152, pp. 383-91.

9. D.R. Clarke and S.R. Phillpot: Materials, 2005, vol. 8, pp. 22-29.

10. L. Sun, H. Guon, H. Peng, S. Gong, and H. Xu: Scripta Mater., 2013, vol. 69, pp. 674-77.

11. L. Wang, J.I. Eldridge, and S.M. Guo: Acta Mater., 2014, vol. 65, pp. $402-10$.

12. P.G. Klemens: Proc. R. Soc. Lond., 1955, vol. A68, pp. 1113-28.

13. A. Feuerstein, J. Knapp, T. Taylor, A. Ashary, A. Bolcavage, and N. Hitchman: J. Therm. Spray Technol., 2008, vol. 17, pp. 199-213.

14. W. Chi, S. Sampath, and H. Wang: J. Am. Ceram. Soc., 2008 , vol. 91, pp. 2636-45.

15. T.R. Kakuda, A.M. Limarga, T.D. Bennett, and D.R. Clarke: Acta Mater., 2009, vol. 57, pp. 2583-91.

16. J. Wu, X. Wei, N.P. Padture, P.G. Klemens, M. Gell, E. Garcia, P. Miranzo, and M.I. Osendi: J. Am. Ceram. Soc., 2002, vol. 85, pp. $3031-35$.

17. N.P. Padture, K.W. Schlichting, T. Bhatia, A. Ozturk, B. Cetegen, E.H. Jordan, M. Gell, S. Jiang, T.D. Xiao, P.R. Strutt, E. Garcia, P. Miranzo, and M.I. Osendi: Acta Mater., 2001, vol. 19 , pp. 2251-57.

18. K. Bobzin, N. Bagcivan, T. Brögelmann, and B. Yildirim: Surf. Coat. Technol., 2013, vol. 237, pp. 56-64.

19. X. Ren, S. Guo, M. Zhao, and W. Pan: J. Mater. Sci., 2014, vol. 49 (5), pp. 2243-51. DOI:10.1007/s10853-013-7919-Z.

20. H. Liu, S. Li, Q. Li, Y. Li, and W. Zhou: Solid State Sci., 2011, vol. 13, pp. 513-19.

21. B.-L. Jang and H. Matsubara: Ceram. Eng. Sci. Proc., 2007, vol. 28, pp. 115-23.

22. B. Saruhan, V. Ryukhtin, and K. Kelm: Surf. Coat. Technol., 2011, vol. 205, pp. 5369-78.

23. A. Flores Renteria, B. Saruhan, U. Schulz, H.-J. Raetzer-Scheibe, J. Haug, and A. Wiedenmann: Surf. Coat. Technol., 2006, vol. 201, pp. 2611-20.

24. J. Singh, D.E. Wolfe, R.A. Miller, J.I. Eldridge, and D.-M. Zhu: J. Mater. Sci., 2004, vol. 39, pp. 1975-85.

25. S Gong, K VanEvery, H Wang, and RW Trice: J. Eur. Ceram. Soc., 2013, vol. 34 (5), pp. 1243-53. DOI:10.1016/j.jeurceramsoc. 2013.11.016.

26. D. Zhu and R.A. Miller: J. Therm. Spray Technol., 2000, vol. 9, pp. $175-80$.

27. R. Mévrel, J.-C. Laizet, A. Azzopardi, B. Leclercq, M. Poulain, O. Lavigne, and D. Demange: J. Eur. Ceram. Soc., 2004, vol. 24, pp. 3081-89.

28. J.-F. Bisson, D. Fournier, M. Poulain, O. Lavigne, and R. Mévrel: J. Am. Ceram. Soc., 2000, vol. 83, pp. 1993-98.

29. M. Fèvre, A. Finel, R. Caudron, and R. Mévrel: Phys. Rev. B, 2005, vol. 72, pp. 104118-1-104118-7.

30. S. Raghavan, H. Wang, R.B. Dinwiddie, W.D. Porter, and M.J. Mayo: Scripta Mater., 1998, vol. 39, pp. 1119-25.

31. S. Raghavan, H. Wang, D. Porter, R.B. Dinwiddie, and M.J. Mayo: Acta Mater., 2001, vol. 49, pp. 169-79.

32. Y Wang, F Yang, and P Xiao: Appl. Phys. Lett., 2013, vol. 102, pp. 141902-1-141902-5.
33. D. Zhu and R.A. Miller: Ceram. Eng. Sci. Proc., 2002, vol. 23, pp. 457-68.

34. R.A. Miller: J. Therm. Spray Technol., 1997, vol. 6, pp. 35-42.

35. S. Stecura: NASA TM 86905, 1985.

36. A. Rauf, Q. Yu, L. Jin, and C. Zhou: Scripta Mater., 2012, vol. 66, pp. 109-12.

37. J. Wu, N.P. Padture, P.G. Klemens, M. Gell, E. García, P. Miranzo, and M.I. Osendi: J. Mater. Res., 2002, vol. 12, pp. 3193-3200.

38. N. Curry, N. Markocsan, L. Östergren, X.-H. Li, and M. Dorfman: J. Thermal Spray Technol., 2013, vol. 22, pp. 864-72.

39. L. Sun, H. Guo, H. Peng, S. Gong, and H. Xu: Prog. Nat. Sci. Mater. Int., 2013, vol. 23, pp. 440-45.

40. U. Schulz, C. Leyens, K. Fritscher, M. Peters, B. Saruhan-Brings, O. Lavigne, J.-M. Dorvaux, M. Poulain, R. Mévrel, and M. Caliez: Aerosp. Sci. Technol., 2003, vol. 7, pp. 73-80.

41. L. Guo, H. Guo, S. Gong, and H. Xu: Ceram. Int., 2013, vol. 39, pp. $9009-15$.

42. Y. Shen, R.M. Leckie, C.G. Levi, and D.R. Clarke: Acta Mater., 2010, vol. 58, pp. 4424-31.

43. R. Vassen, A. Stuke, and D. Stöver: J. Thermal Spray Technol., 2009, vol. 18, pp. 181-86.

44. S.B. Weber, H.L. Lein, T. Grande, and M.-A. Einarsrud: Surf. Coat. Technol., 2013, vol. 227, pp. 10-14.

45. H. Jin, D. Huang, Q. Gao, L. Li, N. Wang, Y. Wang, and S. Hou: Mater. Res. Bull., 2012, vol. 47, pp. 51-53.

46. X. Wang, Y. Zhu, L. Du, and W. Zhang: Appl. Surf. Sci., 2011, vol. 257, pp. 8945-49.

47. H. Chen, Y. Gao, S. Tao, Y. Liu, and H. Luo: J. Alloys Compd., 2009, vol. 486, pp. 391-99.

48. J. Xiang, S. Chen, J. Huang, H. Zhang, and X. Zhao: Ceram. Int., 2012, vol. 38 , pp. 3607-12.

49. J. Xiang, S. Chen, J. Huang, W. Liang, Y. Cao, R. Wang, and Q. He: J. Rare Earths, 2012, vol. 30, pp. 228-32.

50. K.-H. Kwak, B.-C. Shim, S.-M. Lee, Y.-S. Oh, H.-T. Kim, B.-K. Jang, and S. Kim: Mater. Lett., 2011, vol. 65, pp. 2937-40.

51. H. Zhou and D. Yi: J. Rare Earths, 2008, vol. 26, pp. 770-74.

52. C. Wan, W. Zhang, Y. Wang, Z. Qu, A. Du, R. Wu, and W. Pan: Acta Mater., 2010, vol. 58, pp. 6166-72.

53. Y. Wang, F. Yang, and P. Xiao: Acta Mater., 2012, vol. 60, pp. 7024-33.

54. R. Vassen, X. Cao, F. Tietz, D. Basu, and D. Stöver: J. Am. Ceram. Soc., 2000, vol. 83, pp. 2023-28

55. C.L. Wan, W. Pan, Q. Xu, Y.X. Qin, J.D. Wang, Z.X. Qu, and M.H. Fang: Phys. Rev. B, 2006, vol. 74, pp. 144109-1-144109-9.

56. J. Feng, B. Xiao, R. Zhou, and W. Pan: Scripta Mater., 2013, vol. 68 , pp. 727-30.

57. P.K. Schelling, S.R. Phillpot, and R.W. Grimes: Philos. Mag. Lett., 2004, vol. 84, pp. 127-37.

58. H. Lehmann, D. Pitzer, G. Pracht, R. Vassen, and D. Stöver: $J$. Am. Ceram. Soc., 2003, vol. 86, pp. 1338-44.

59. G. Moskal, L. Swadźba, M. Hetmańczyk, B. Witala, B. Mendala, J. Mendala, and P. Sosnowy: J. Eur. Ceram. Soc., 2012, vol. 32, pp. 2025-34.

60. L. Guo, H. Guo, H. Peng, and S. Gong: J. Eur. Ceram. Soc., 2014, vol. 34 (5), pp. 1255-63. DOI:10.1016/j.jeurceramsoc.2013.11.035.

61. W. Pan, C.L. Wan, Q. Xu, J.D. Wang, and Z.X. Qu: Thermochim. Acta, 2007, vol. 455, pp. 16-20.

62. J. Yu, H. Zhao, S. Tao, X. Zhou, and C. Ding: J. Eur. Ceram. Soc., 2010, vol. 30, pp. 799-804.

63. H.-S. Zhang, K. Sun, Q. Xu, F.-C. Wang, and L. Liu: J. Mater. Eng. Perform., 2009, vol. 18, pp. 1140-43.

64. H. Zhang, K. Sun, Q. Xu, F. Wang, L. Liu, Y. Wei, and X. Chen: Rare Met., 2009, vol. 28, pp. 226-30.

65. H. Zhang, Xu. Qiang, F.-C. Wang, L. Ling, W. Yuan, and C. Xiaoge: J. Alloys Compd., 2009, vol. 475, pp. 624-28.

66. C. Wan, Z. Qu, A. Du, and W. Pan: J. Am. Ceram. Soc., 2011, vol. 94 , pp. 592-96.

67. G. Suresh, G. Seenivasan, M.V. Krishnaiah, and P.S. Murti: $J$. Alloys Compd., 1998, vol. 269, pp. L9-L12.

68. G. Moskal, L. Swadźba, M. Hetmańczyk, B. Witala, B. Mendala, J. Mendala, and P. Sosnowy: J. Eur. Ceram. Soc., 2012, vol. 32, pp. 2035-42.

69. Q. Xu, W. Pan, J. Wang, C. Wan, L. Qi, H. Miao, K. Mori, and T. Torigoe: J. Am. Ceram. Soc., 2006, vol. 89, pp. 340-42. 
70. K.S. Lee, K.I. Jung, Y.S. Heo, T.W. Kim, Y.-G. Jung, and U. Paik: J. Alloys Compd., 2010, vol. 507, pp. 448-55.

71. L. Guo, H. Guo, and S. Gong: Mater. Lett., 2013, vol. 106, pp. 119-21.

72. C. Wang, Y. Wang, X. Fan, W. Huang, B. Zou, and X. Cao: Surf. Coat. Technol., 2012, vol. 212, pp. 88-93.

73. Z. Xu, L. He, X. Zhong, R. Mu, S. He, and X. Cao: J. Alloys Compd., 2009, vol. 478, pp. 168-72.

74. Q. Li, Z. Lin, and J. Zhou: J. Electron. Mater., 2009, vol. 38, pp. $1268-72$

75. Z. Hongsong, L. Jianguo, L. Gang, Z. Zheng, and W. Xinli: Mater. Res. Bull., 2012, vol. 47, pp. 4181-86.

76. Z. Hongsong, Y. Shuqing, and C. Xiaoge: J. Eur. Ceram. Soc., 2014, vol. 34, pp. 55-61.

77. W. Ma, D.E. Mack, R. Vaßen, and D. Stöver: J. Am. Ceram. Soc., 2008, vol. 91, pp. 2630-35.

78. W. Ma, D. Wang, H. Dong, W. Lun, W. He, and X. Zheng: $J$. Therm. Spray Technol., 2013, vol. 22, pp. 104-109.

79. W. Ma, P. Li, H. Dong, Y. Bai, J. Zhao, and X. Fan: J. Therm. Spray Technol., 2014, vol. 23, pp. 154-59.

80. Z. Qu, T.D. Sparks, W. Pan, and D.R. Clarke: Acta Mater., 2011, vol. 59, pp. 3841-50.

81. B. Liu, J.Y. Wang, F.Z. Li, and Y.C. Zhou: Acta Mater., 2010, vol. 58, pp. 4369-77.

82. E.Ya. Litovsky and M. Shapiro: J. Am. Ceram. Soc., 1992, vol. 75 , pp. 3425-39.

83. S. Sampath, U. Schulz, M.O. Jarligo, and S. Kuroda: MRS Bull., 2012, vol. 37, pp. 903-10.

84. M. Gupta, G. Dwivedi, P. Nylén, A. Vackel, and S. Sampath: $J$. Therm. Spray Technol., 2013, vol. 22, pp. 659-70.

85. J.D. Osorio, J.P. Hernández-Ortiz, and A. Toro: Ceram. Int., 2014, vol. 40, pp. 4663-71.

86. J.D. Osorio, D. Maya, A.C. Barrios, A. Lopera, F. Jiménex, J.M. Meza, J.P. Hernández-Ortiz, and A. Toro: J. Am. Ceram. Soc., 2013, vol. 96, pp. 3901-907.

87. J. Chevalier, L. Gremillard, A.V. Virkar, and D.R. Clarke: $J$. Am. Ceram. Soc., 2009, vol. 92, pp. 1901-20.

88. J.A. Krogstad, S. Krämer, D.M. Lipkin, C.A. Johnson, D.R.G. Mitchell, J.M. Cairney, and C.G. Levi: J. Am. Ceram. Soc., 2011, vol. 94, pp. S168-S177.

89. S. Ahmaniemi, M. Vippola, P. Vuoristo, T. Mäntylä, F. Cernuschi, and L. Lutterotti: J. Eur. Ceram. Soc., 2004, vol. 24, pp. 2247-58.

90. K. Jiang, S. Liu, Y. Li, and Y. Li: J. Am. Ceram. Soc., 2014, vol. 97 , pp. 990-95.

91. C.G. Levi, J.W. Hutchinson, M.-H. Vidal-Sétif, and C.A. Johnson: MRS Bull., 2012, vol. 37, pp. 932-41.

92. D.M. Lipkin, J.A. Krogstad, Y. Gao, C.A. Johnson, W.A. Nelson, and C.G. Levi: J. Am. Ceram. Soc., 2013, vol. 96, pp. 290-98.

93. J.A. Krogstad, R.M. Leckie, S. Krämer, J.M. Cairney, D.M. Lipkin, C.A. Johnson, and C.G. Levi: J. Am. Ceram. Soc., 2013, vol. 96, pp. 299-307.

94. S. Wei, W. Fu-chi, F. Qun-bo, and M. Zhuang: Surf. Coat. Technol., 2013, vol. 217, pp. 39-45.

95. R.V. Hillery, B.H. Pilsner, R.L. McKnight, T.S. Cook, and M.S. Hartie: NASA-CR-180807, 1988.

96. Y. Bai, L. Zhao, K. Liu, J.J. Tang, and Z.H. Han: Vacuum, 2014, vol. 99, pp. 119-23.

97. L. Wang, Y. Wang, X.G. Sun, J.Q. He, Z.Y. Pan, and C.H. Wang: Ceram. Int., 2012, vol. 38, pp. 3595-3606.

98. M. Shinozaki and T.W. Clyne: Acta Mater., 2013, vol. 61, pp. 579-88.

99. S. Kyaw, A. Jones, and T. Hyde: Eng. Fail. Anal., 2013, vol. 27, pp. $150-64$.

100. X. Zhao, X. Wang, and P. Xiao: Surf. Coat. Technol., 2006, vol. 200 , pp. $5946-55$.

101. K. Jiang, S. Liu, and C. Li: J. Am. Ceram. Soc., 2013, vol. 96, pp. 3296-3303.

102. V. Lughi, V.K. Tolpygo, and D.R. Clarke: Mater. Sci. Eng. A, 2004, vol. 368, pp. 212-21.

103. Y. Sun, J. Li, W. Zhang, and T.J. Wang: Surf. Coat. Technol., 2013, vol. 216, pp. 237-50.

104. M. Bäker: Comput. Mater. Sci., 2012, vol. 64, pp. 79-83.

105. R. Kitazawa, H. Kakisawa, and Y. Kagawa: Surf. Coat. Technol., 2014, vol. 238, pp. 68-74.

106. F. Riallant, J. Cormier, A. Longuet, X. Milhet, and J. Mendez: Metall. Mater. Trans. A., 2014, vol. 45A, pp. 351-60.
107. S. Ahmadian, C. Thistle, and E.H. Jordan: J. Am. Ceram. Soc., 2013, vol. 96, pp. 3210-17.

108. B. Heeg, V.K. Tolpygo, and D.R. Clarke: J. Am. Ceram. Soc., 2011, vol. 94, pp. S112-S119.

109. Z. Xu, G. Huang, L. He, R. Mu, K. Wang, and J. Dai: J. Alloys Compd., 2014, vol. 586, pp. 1-9.

110. A.U. Munawar, U. Schulz, and G. Cerri: J. Eng. Gas Turbines Power, 2013, vol. 135, pp. 102101-1-102101-6.

111. Z. Xu, L. He, X. Zhong, J. Zhang, X. Chen, H. Ma, and X. Cao: J. Alloys Compd., 2009, vol. 480, pp. 220-24.

112. J. Wang, S. Bai, H. Zhang, and C. Zhang: J. Alloys Compd., 2009, vol. 476, pp. 89-91.

113. D. Zhu and R.A. Miller: Surf. Coat. Technol., 1998, vols. 108109, pp. 114-20.

114. F.H. Stott, D.J. de Wet, and R. Taylor: MRS Bull., 1994, vol. 19, pp. 46-49.

115. M.P. Borom, C.A. Johnson, and L.A. Peluso: Surf. Coat. Technol., 1996, vols. 86-87, pp. 116-26.

116. S. Krämer, J.Y. Yang, C.A. Johnson, and C.G. Levi: J. Am. Ceram. Soc., 2006, vol. 89, pp. 3167-75.

117. W. Braue and P. Mechnich: J. Am. Ceram. Soc., 2011, vol. 94, pp. 4483-89.

118. A. Aygun, A.L. Vasiliev, and N.P. Padture: Acta Mater., 2007, vol. 55 , pp. $6834-45$

119. A.D. Gledhill, K.M. Reddy, J.M. Drexler, K. Shinoda, S. Sampath, and N.P. Padture: Mater. Sci. Eng. A, 2011, vol. 528, pp. 7214-21.

120. M.H. Vidal-Setif, N. Chellah, C. Rio, C. Sanchez, and O. Lavigne: Surf. Coat. Technol., 2012, vol. 208, pp. 39-45.

121. R.G. Wellman and J.R. Nicholls: Tribol. Int., 2008, vol. 41, pp. 657-62.

122. M.H. Vidal-Sétif, C. Rio, D. Boivin, and O. Lavigne: Surf. Coat. Technol., 2014, vol. 239, pp. 41-45. DOI:10.1016/j.surfcoat. 2013.11.014.

123. P. Mechnich, W. Braue, and U. Schulz: J. Am. Ceram. Soc., 2011, vol. 94, pp. 925-31.

124. Y. Hemberger, C. Berthold, and K.G. Nickel: J. Eur. Ceram. Soc., 2012, vol. 32, pp. 2859-66.

125. R. Ahmadi-Pidanin, R. Shoja-Razavi, R. Mozafarinia, and H. Jamali: Ceram. Int., 2012, vol. 38, pp. 6613-20.

126. C. Mercer, S. Faulhaber, A.G. Evans, and R. Darolia: Acta Mater., 2005, vol. 53, pp. 1029-39.

127. S. Krämer, S. Faulhaber, M. Chambers, D.R. Clarke, C.G. Levi, J.W. Hutchinson, and A.G. Evans: Mater. Sci. Eng. A, 2008, vol. 490, pp. 26-35.

128. H. Peng, L. Wang, L. Guo, W. Miao, H. Guo, and S. Gong: Prog. Natural Sci. Mater. Int., 2012, vol. 22, pp. 461-67.

129. R. Wellman, G. Whitman, and J.R. Nicholls: Int. J. Refract. Met. Hard Mater., 2010, vol. 28, pp. 124-32.

130. T. Steinke, D. Sebold, D.E. Mack, R. Vaßen, and D. Stöver: Surf. Coat. Technol., 2010, vol. 205, pp. 2287-95.

131. M. Shinozaki and T.W. Clyne: Surf. Coat. Technol., 2013, vol. 216, pp. 172-77.

132. X. Chen: Surf. Coat. Technol., 2006, vol. 200, pp. 3418-27.

133. A.G. Evans and J.W. Hutchinson: Surf. Coat. Technol., 2007, vol. 201, pp. 7905-16.

134. L. Li and D.R. Clarke: Int. J. Appl. Ceram. Technol., 2008, vol. 5, pp. 278-88.

135. J. Wu, H.-B. Guo, Y.-Z. Gao, and S.-K. Gong: J. Eur. Ceram. Soc., 2011, vol. 31, pp. 1881-88.

136. P. Mohan, B. Yao, T. Patterson, and Y.H. Sohn: Surf. Coat. Technol., 2009, vol. 204, pp. 797-801.

137. J.M. Drexler, K. Shinoda, A.L. Ortiz, D. Li, A.L. Vasiliev, A.D. Gledhill, S. Sampath, and N.P. Padture: Acta Mater., 2010, vol. 58 , pp. $6835-44$.

138. C. Ren, Y.D. He, and D.R. Wang: Surf. Coat. Technol., 2011, vol. 206, pp. 1461-68.

139. J. Yao, Y. He, D. Wang, H. Peng, H. Guo, and S. Gong: Corros. Sci., 2014, vol. 80, pp. 37-45.

140. A.K. Rai, R.S. Bhattacharya, D.E. Wolfe, and T.J. Eden: Int. J. Appl. Ceram. Technol., 2010, vol. 7, pp. 662-74.

141. I.P. Downs, J.H. Perepezko, R. Sakidja, and S.R. Choi: Surf. Coat. Technol., 2014, vol. 239, pp. 138-46. DOI:10.1016/j.surf coat.2013.11.032. 
142. N.L. Ahlborg and D. Zhu: Surf. Coat. Technol., 2013, vol. 236, pp. 79-87.

143. N.K. Eils, P. Mechnich, and W. Braue: J. Am. Ceram. Soc., 2013, vol. 96 , pp. 3333-40.

144. J.M. Drexler, A.L. Ortiz, and N.P. Padture: Acta Mater., 2012, vol. 60 , pp. $5437-47$.

145. C.S. Ramachandran, V. Balasubramanian, and P.V. Ananthapadmanabhan: Ceram. Int., 2013, vol. 39, pp. 1413-31.

146. C.S. Ramachandran, V. Balasubramanian, P.V. Ananthapadmanabhan, and V. Viswabaskaran: Ceram. Int., 2012, vol. 38, pp. 4081-96.

147. S. Krämer, J.Y. Yang, and C.G. Levi: J. Am. Ceram. Soc., 2008, vol. 91, pp. 576-83.

148. J.M. Drexler, C.H. Chen, A.D. Gledhill, K. Shinoda, S. Sampath, and N.P. Padture: Surf. Coat. Technol., 2012, vol. 206, pp. 3911-16.

149. M.H. Habibi, L. Wang, and S.M. Guo: J. Eur. Ceram. Soc., 2012, vol. 32, pp. 1635-42.
150. R.M. Leckie, S. Krämer, M. Rühle, and C.G. Levi: Acta Mater., 2005, vol. 53, pp. 3281-91.

151. O. Fabrichnaya and H.J. Seifert: J. Phase Equilib. Diffus., 2011, vol. 32 , pp. $2-16$.

152. Z.H. Xu, X. Zhou, K. Wang, J.W. Dai, and L.M. He: J. Alloys Compd., 2014, vol. 587, pp. 126-32.

153. Y. Bai, J.J. Tang, Y.M. Qu, S.Q. Ma, C.H. Ding, J.F. Yang, L. Yu, and Z.H. Han: Ceram. Int., 2013, vol. 39, pp. 5113-24.

154. M. Han, J. Huang, and S. Chen: Ceram. Int., 2014, vol. 40, pp. 2901-14.

155. S. Zhao, L. Gu, Y. Zhao, W. Huang, L. Zhu, X. Fan, B. Zou, and X. Cao: J. Alloys Compd., 2013, vol. 580, pp. 101-107.

156. H. Dong, D. Wang, Y. Pei, H. Li, P. Li, and W. Ma: Ceram. Int., 2013, vol. 39, pp. 1863-70.

157. R. Vaßen, M.O. Jarligo, T. Steinke, D.E. Mack, and D. Stöver: Surf. Coat. Technol., 2010, vol. 205, pp. 938-42.

158. H. Zhao, M.R. Begley, A. Heuer, R. Sharghi-Moshtaghin, and H.N.G. Wadley: Surf. Coat. Technol., 2011, vol. 205, pp. 4355-65. 